The following document is a pre-print version of:

Ross, P.-S., Delpit, S., Haller, M.J., Németh, K. et Corbella, H. (2011) Influence of the substrate on maar-diatreme volcanoes - an example of a mixed setting from the Pali Aike volcanic field, Argentina. Journal of Volcanology and Geothermal Research, v. 201, p. 253-271

\title{
Influence of the substrate on maar-diatreme volcanoes - an example of a mixed setting from the Pali Aike volcanic field, Argentina
}

\author{
Pierre-Simon Ross ${ }^{1}$, Séverine Delpit ${ }^{1}$, Miguel J. Haller ${ }^{2}$, Károly Németh ${ }^{3}$ \\ and Hugo Corbella
}

1. Institut national de la recherche scientifique, 490 rue de la Couronne, Québec (QC), G1K 9A9, Canada, Phone 1-418654-3773, Fax. 1-418-654-2600, email rossps@ete.inrs.ca

2. CentroUniversidad Nacional Patagónico-UNPSJBde la Patagonia San Juan Bosco - CONICET, Avda. Boulevard Brown 35003700, (9120) Puerto Madryn, Chubut, Argentina

3. Volcanic Risk Solutions, Massey University, Private Bag 11 222, Palmerston North, New Zealand

4. Museo Argentino de Ciencias Naturales, Avenida Angel Gallardo 470, Buenos Aires, Argentina

Keywords: Argentina, maar, phreatomagmatism, hard substrate, soft substrate

\begin{abstract}
The morphologic parameters, pyroclastic deposits and evolution of maar-diatreme volcanoes are affected by the type of environment in which they are emplaced. End-member cases are a hard substrate (rocks) and a soft substrate (unconsolidated volcaniclastic or sedimentary deposits). In this paper, we present an example of a volcanic complex emplaced in a mixed hard-soft setting from the Pali Aike volcanic field (PAVF) near the Argentina-Chile border. The PlioPleistocene PAVF is an alkaline, mafic, back-arc monogenetic field which contains over 100 phreatomagmatic volcanoes. The studied volcanic complex contains two large coalescent maars overlain by scoria and spatter. The 1.4x1.3 km East Maar has better exposures than the shallower, $1.9 \mathrm{~km}$-wide West Maar and seems to have been less modified by post-eruptive processes. The tephra rim of the East Maar was studied in detail and we infer it was produced mostly by base surges from phreatomagmatic eruption columns, with rare instances of intercalated scoria fall layers. Based on regional information, the general pre-maar stratigraphy is dominated by sedimentary and volcaniclastic rocks of the Magallanes Basin, including a thick poorly consolidated upper unit dating from the Miocene. These are overlain by Plio-Pleistocene fluvio-glacial deposits and PAVF lavas, some of which are exposed in the East Maar just below the phreatomagmatic deposits. All of these units are represented as lithic clasts in the tephra rim of the East Maar, the most abundant being the clasts from the earlier basaltic lavas and rock fragments derived from the glacial deposits. There is no specific evidence for a deep diatreme under the East Maar, and in this particular case, the mixed environment seems to have produced a maar-diatreme volcano typical of a soft substrate.
\end{abstract}

\section{Introduction}

Because monogenetic volcanoes are created by comparatively low-volume, low intensity eruptions, the environment in which they occur is an important control on the style of activity - explosive or effusive, magmatic or phreatomagmatic - and consequently on the type of volcanic edifice formed. Maar-diatreme volcanoes are formed on land when rising magma, of any composition and gas content, meets groundwater (Lorenz, 1975, 1986; Fisher and Schmincke, 1984). Often the groundwater supply becomes exhausted during the course of a maarforming eruption and the activity changes to strombolian (scoria cone-forming) or to the generation of lava flows or lava lakes, depending on the properties of the magma. This pattern of phreatomagmatic activity switching more or less abruptly to magmatic activity ("drying out") in maar volcanoes is typical all over the world. Examples include the East Eifel volcanic field of Germany (Houghton and Schmincke, 1986); the West Eifel volcanic field (Lorenz and Zimanowski, 2008, and references therein); several sites in Mexico (e.g., Aranda-Gómez et al., 1992; Ort and Carrasco-Núñez, 2009); and the Auckland volcanic field in New Zealand (Houghton et al., 1999).

Maar tephra rims always contain, apart from juvenile fragments, abundant material derived from the 
pre-maar rocks or unconsolidated deposits. This abundant dilution of juvenile particles by lithic clasts arises because of the excavation of the maar crater and underlying diatreme by the phreatomagmatic explosions. Lithic clasts in maar tephra rims contain information on the lithology of the substrate, the depth of the explosions and, of particular interest here, on the state of lithification of the substrate.

The two end-member types of substrate for maardiatreme volcanism are "soft" unconsolidated deposits (sediments or volcaniclastic deposits) and "hard" rocks (Lorenz, 2003). Mixed settings, in which both rocks and unconsolidated deposits occur, are also common. The type of substrate controls the type of aquifer in which the external water sits (fracture-controlled vs. porous aquifers); the overall shape of the volcano including the diatreme; the post-eruptive lacustrine architecture in the maar crater; and some characteristics of the pyroclastic deposits of the tephra rim and diatreme (Lorenz, 2003; Auer et al., 2007; Martín-Serrano et al., 2009).

Emplacement of maars in hard substrates is relatively well known, for example in the West Eifel volcanic field (e.g., Lorenz, 1987; Büchel, 1993; Lorenz and Zimanowski, 2008), but maars emplaced in soft substrates, or mixed substrates - where hydrologic conditions may be more complex - are less well documented (although see for example White, 1991; Sohn, 1996; and Sohn and Park, 2005). Specifically, there exists a shortage of contributions presenting single maars or maar complexes and their soft or mixed substrates in detail in the literature. In this paper, we describe a twomaar complex emplaced in a mixed setting from the Pali Aike volcanic field (PAVF), near the Argentina-Chile border (Figs. 1, 2). We also summarize what is currently known about maars emplaced in different types of substrates. Better understanding the influence of the external environment on eruptive processes and deposits of basaltic monogenetic volcanoes has the added benefit of potentially shedding light on kimberlite emplacement processes (e.g., McClintock et al., 2009).

\section{Geological context}

\subsection{Tectonic setting}

The Plio-Pleistocene PAVF covers $\sim 4500 \mathrm{~km}^{2}$ in southern Argentina and Chile (Corbella, 2002; Fig. 1). It represents the southernmost occurrence of the Cenozoic Patagonian Plateau Lavas (e.g., Tyrrell, 1932; Corbella and Lara, 2008). Relative to the modern volcanic arc in the Andes, the Patagonian Plateau Lavas occur in a backarc position. The PAVF eruptive products are alkaline and typically olivine-bearing, ranging from basalts to basanites, and have trace element signatures similar to those of ocean island basalts (OIB) (Skewes and Stern, 1979; D'Orazio et al., 2000). No "subduction" signature is detectable in the geochemical composition of the erupted products, leading to slab-window models for the PAVF volcanism (e.g., D'Orazio et al., 2000; Wang et al., 2008), in common with other volcanic fields further north (e.g., Ramos and Kay, 1992). However, some workers now prefer a slab rollback model for back-arc volcanism in this region (e.g., Muñoz et al., 2000; de Ignacio et al., 2001).

Mazzarini and D'Orazio (2003) analyzed PAVF lineaments on a satellite image and found that $77 \%$ of these lineaments fall into four main families: $\mathrm{N}-\mathrm{S}$ (azimuth range $\left.350^{\circ}-010^{\circ}\right)$, NE-SW $\left(021^{\circ}-060^{\circ}\right)$, E-W $\left(080^{\circ}-100^{\circ}\right)$ and NW-SE $\left(110^{\circ}-150^{\circ}\right)$. In the subpopulation of lineaments belonging to the four families, the relative proportions of lineaments in each family is $13 \%, 29 \%, 12 \%$ and $46 \%$, respectively. The two most common trends, NW-SE and NE-SW, are the most apparent on figure 2 . The elongation of the volcanic edifices themselves, based on topographic maps, field surveys and aerial photos, follows the same structural orientations (Mazzarini and D'Orazio, 2003). Some of these trends may be related to extension during the Neogene (Diraison et al., 1997) while other trends may be inherited from older events.

\subsection{Underlying to contemporary rocks and deposits}

The PAVF eruptive products stratigraphically overlie the hydrocarbon-producing Magallanes Basin (also known as the Austral Basin). The foreland basin infill sequence is up to $8 \mathrm{~km}$-thick (Ramos, 1989; Fig. 1). In the PAVF area, the basin infill sequence reaches 2 to $3 \mathrm{~km}$ in thickness (Biddle et al., 1986), and starts with the Jurassic silicic volcanic rocks of the Tobífera Formation (or Chon Aike Formation), which is part of the Chon Aike igneous province (Pankurst et al., 1998). More than $1 \mathrm{~km}$ of marine sedimentary rocks of Cretaceous to Lower Miocene age overlie the Tobífera Formation (Zilli et al., 2002). The youngest formation in the Magallanes Basin is the Miocene, semi-consolidated Santa Cruz Formation, composed predominantly of continental sandstones (Nullo and Combina, 2002). Since about $14 \mathrm{Ma}$, a rain shadow due to uplift of the Andes seems to have largely prevented sedimentation in the basin (Blisniuk et al., 2005).

Glaciations occurred during the Plio-Pleistocene in the general PAVF area, approximately between 3.5 and 1.0 Ma (Zolitschka et al., 2006), leaving fluvioglacial deposits on top of the Santa Cruz Formation, including moraines and gravels. Since the radiometric age range of PAVF volcanism is 3.78 to $0.17 \mathrm{Ma}$ (as compiled by Mazzarini and D'Orazio, 2003), glacio-volcanic interactions may have occurred during the history of the PAVF, but have not yet been documented to our knowledge. The bulk of the volcanism is younger than $1.5 \mathrm{Ma}$ and the maar complex described here is clearly post-glacial (details below).

\subsection{PAVF stratigraphy}

The volcanic field has been informally divided into three stratigraphic units, U1 to U3, by D'Orazio et al. (2000). The oldest and most extensive unit, U1, consists of tabular lava flows which collectively form a plateau. This succession can reach $120 \mathrm{~m}$ in thickness. Unit U2 consists of over 450 variably dissected, mainly monogenetic volcanic edifices with subsidiary lava flows. 
The edifices include over 100 phreatomagmatic volcanoes, i.e. maars and tuff rings (Corbella, 2002), and are found at elevations ranging between 100 and $180 \mathrm{~m}$ above sea level. The other volcanoes are mostly scoria cones, but they are not known in any detail. A layer of eolian soil ( \pm grass) typically covers the U2 eruptive products. The volcanic complex discussed in this paper belongs to unit U2, and so does the larger Potrok Aike maar about $15 \mathrm{~km}$ to the WNW (Zolitschka et al., 2006; Corbella et al., 2009a). The only phreatomagmatic sequence described in detail to date from the PAVF, that of the "Tito" maar, also belongs to U2 (Haller and Nemeth, 2006). Finally unit U3, which occurs only in the SE part of the field, consists of young scoria cones and lava flows with little eolian soil cover. The young volcano containing Laguna Azul, for example, belongs to U3 (Corbella et al., 2009b).

\section{The volcanic complex: overview \\ 3.1 Location and interest}

The volcanic complex described here (and briefly by Haller et al., 2006) is located in the SW portion of the PAVF at around $70.155^{\circ} \mathrm{W}, 51.995^{\circ} \mathrm{S}$ (Fig. 2). It is possible to drive there with a $4 \times 4$ vehicle using a network of private unpaved roads originating from Ruta Nacional 40 , about $24 \mathrm{~km}$ to the NW (Fig. 3a). The complex contains some of the best maar tephra rim outcrops we have seen on the Argentinean side of the volcanic field in this area. The East Maar, in particular, represents a prime example of a relatively well preserved maar in the PAVF (Figs. 4, 5a). A better understanding of what maar rim deposits actually look like in the PAVF will be useful in order to interpret the volcaniclastic deposits found around Laguna Potrok Aike (the lacustrine sediments at the bottom of this lake have been cored as part of an ICDP project recently).

The volcanic complex consists of two overlapping maars, including their tephra rims, overlain by scoria and spatter (Fig. 3b). The maars and accompanying tephra rims are described in more detail below.

\subsection{Pre-maar volcanic sequence}

A thin pre-maar volcanic sequence is known from field station PAVF-025 and vicinity, in the East Maar (Fig. 3a). It consists of a $70 \mathrm{~cm}$-thick well sorted scoriaceous lapilli fall deposit (Figs. 5b, 5c), overlain by a $4.5 \mathrm{~m}$-thick olivine-phyric basaltic lava flow (Fig. 5b) which appears highly fractured and contains peridotite nodules. Elsewhere in the volcanic complex, the nature of the material immediately underlying the maar tephra rim deposits is not directly observable, but a basaltic lava flow is also exposed at low elevations just north of the East Maar (PAVF-035), suggesting that lava flows underlie a significant portion of the complex.

\subsection{Post-maar scoria and spatter}

The edifices of which the scoria and spatter overlying the maar tephra rim deposits were originally part have been variably eroded, but at least two vents are inferred for the scoria and spatter accumulations: one centred on the West Maar and the other centred on the junction area of the two maars. These late vents were presumably located on the same E-W fissure which first controlled the emplacement of the two maars. The western vent has left a crescent-shaped accumulation of scoria and spatter well visible on the aerial photographs (Fig. 3a). The crescent is open to the west, likely because of strong easterly winds during the eruption (Fig. 5d). The spatterdominated zones consist of dm-size dense to moderately vesicular juvenile bombs in a red scoriaceous coarse ash matrix. The basal parts of the exposed spatter sequences are coherent-looking and rich in peridotite nodules up to $30 \mathrm{~cm}$ across (Fig. 5e). In contrast, maar tephra rim deposits do not contain large non-fragmented mantle nodules.

The deposits of the other inferred late vent, in the maar junction area, do not create an obvious circular or crescent shape on the aerial photographs, although a crescent pattern is observable in the field. In this sector, erosion has left spatter and scoria in two areas (Fig. 3b). The northern area has beautiful cliff exposures, up to 15$20 \mathrm{~m}$ high, of welded spatter (Fig. 5f) with some peridotite nodules. At this location a clast of till has been observed within the spatter (Fig. 5g), demonstrating that glacial deposits immediately underlie the volcanic complex, likely just below the lava flows.

\section{The East Maar}

\subsection{General characteristics}

The eastern maar crater has a near elliptical shape, with dimensions $1.40 \mathrm{~km} \mathrm{E-W}$ by $1.28 \mathrm{~km} \mathrm{~N}-\mathrm{S}$, and a depth of $89 \mathrm{~m}$ (to the lake level) along profile A-A' (Figs. $3 a, 4)$. The differential GPS survey made to establish profile A-A' was performed approximately N-S, to avoid the interference area between the two maars which creates a high point in the NW corner of the East Maar. The crater bottom is occupied by a saline lake known informally as Laguna del Ruido.

Excluding the interference area, the maar rim deposits are highest on the eastern side of the East Maar, presumably due to strong easterly winds during the eruption. Along profile A-A', the maximum exposed thickness of tephra rim deposits is about $30 \mathrm{~m}$ (on the NE end of the profile), but the base of these deposits is not exposed and their top may have been eroded, so it is likely that the original thickness was more than $30 \mathrm{~m}$. At the other end of the profile, the tephra rim is thinner, and the beds dip gently outward, sub-parallel to the modern ground surface. This is where the pre-maar volcanic sequence can be observed (see above). In general, maar tephra rim layers are seen, through the soil and grass cover, to undulate gently, suggesting that the pre-eruptive surface was slightly uneven.

\subsection{Detailed stratigraphic log of maar tephra rim deposits}

All the tephra rim outcrops observed are on the inner slope of the maar. The best of these outcrops, at 
station PAVF-021 (Fig. 3a), exposes $4.9 \mathrm{~m}$ of layered deposits which were logged in detail (Figs. 6, 7a). Most of the layers from this outcrop are palagonitized, poorly sorted, and are interpreted as phreatomagmatic in origin (detailed justification: see section 8.1); they are typical maar tephra rim layers. Two scoria fall layers, interpreted as the products of very minor 'magmatic' phases during the maar eruption, are intercalated in this sequence: they are coarser grained, better sorted, contain fewer lithics, and are not palagonitized. Overall in the East Maar these scoria fall layers likely form a negligible proportion of the total thickness of tephra rim deposits (at Ukinrek East, by contrast, there are 35 scoria layers intercalated with the phreatomagmatic deposits; Büchel and Lorenz, 1993). The remainder of this section deals exclusively with the phreatomagmatic layers in the logged section.

The phreatomagmatic layers typically have a brown colour due to palagonitization of some of the juvenile lapilli and of the tuff matrix. Layers range in thickness from a few $\mathrm{mm}$ to $40 \mathrm{~cm}$. Most of the coarse tuff beds are found in the lower $3 \mathrm{~m}$ of the logged section, where they alternate with lapilli-tuff (LT) beds (Fig. 7b). The LT beds are dominant overall (by thickness) in the section.

LT beds are typically $10-40 \mathrm{~cm}$ thick, poorly sorted (visual estimate) and mostly non-graded. Diffuse internal stratification is seen in some of the finer-grained beds but the majority are massive (Fig. 6). Most clasts in LT layers are $<5 \mathrm{~cm}$ across, but a few bombs of lithic basalt (from older lavas), reaching up to $65 \mathrm{~cm}$ in horizontal dimension, are present.

The lapilli fraction of the LT beds comprises $\sim 40 \%$ lithics on average (visual estimate), at least half of which are mafic lava fragments (Figs. 7c, 7d). These were derived from pre-maar lava flows at very shallow depths below the pre-eruptive surface. The other lithics include some rounded pebbles (Fig. 7c) likely derived from unconsolidated fluvio-glacial deposits, also from very shallow depths. Deeper formations of the Magallanes Basin are probably represented by well-indurated sedimentary fragments (quartzite, beige siltstone, red shale, and pink to orange sandstone; Fig. 7d). These "deep" lithics may even include a few reddish clasts from the Tobífera Formation (Fig. 7e), likely sampled at depth more than a kilometre below the pre-eruptive surface, but these could have been brought up by the rising dike.

Juvenile clasts, which are abundant, seem to include both sideromelane (mostly altered to palagonite and clays, except in a few rare cases where glass is preserved) and tachylite fragments. Some of the vesicular tachylite clasts could represent recycled pre-maar scoria, but the observed pre-maar scoria fall layer is much too thin to be the source of all tachylite clasts. So the majority of tachylite fragments must be juvenile particles.

Minor components of the lapilli fraction of the studied LT beds are sparse fragmented peridotite nodules, and traces of accretionary lapilli. The latter are up to $1 \mathrm{~cm}$ across and consist of a large core of agglomerated ash with a thin rim of slightly finer ash (Fig. 7f).
The coarse tuff beds are up to $20 \mathrm{~cm}$ thick but typically less than $10 \mathrm{~cm}$ thick. They range from internally laminated to massive. They most commonly comprise planar laminations, but two beds display low-angle $\left(<10^{\circ}\right)$ cross-lamination typical of pyroclastic surge deposits (e.g., Fig. 8a). Some coarse tuff beds were partially eroded by succeeding surges, forming shallow channels up to $1 \mathrm{~m}$-wide and $10 \mathrm{~cm}$-deep, typically filled by LT (Fig. $8 b)$. Other tuff beds, especially the thinnest ones, undulate slightly since they rest on LT beds that are uneven in thickness (Fig. 7b).

In thin section, the coarse ash fraction of the LT beds (including the smallest lapilli for petrographic purposes) and that of the coarse tuff beds is seen to consist of:

- $5-10 \%$ largely palagonitized (former sideromelane) juvenile fragments, $\sim 0.1$ to $4 \mathrm{~mm}$ across, with $0-50 \%$ largely unfilled, circular vesicles (mostly $\leq 0.3 \mathrm{~mm}$ ). Abundant olivine phenocrysts are found inside the clasts. A few nearly pristine sideromelane shards are seen (Fig. 9a), but most are thoroughly palagonitized or altered to clays (Fig. 9, several photos);

- $2-10 \%$ tachylite fragments with $>50 \%$ vesicles, interpreted as a mixture of recycled pre-maar scoria (lithic fragments) and true juvenile clasts;

- $20-55 \%$ mafic lithic fragments with $0-50 \%$ vesicles, interpreted as pieces of PAVF lava flows from the substrate. Abundant olivine phenocrysts are found in the fragments. Most clasts have a tachylitic groundmass whereas a few appear finely crystalline. No sideromelane (Figs. 9a-9e);

- $10-25 \%$ fragments of sedimentary rocks $(\leq 1 \mathrm{~cm}$ across), sub-angular to rounded in shape, ranging from sandstone to mudstone, derived from the fluvioglacial deposits and stratigraphic units older than the Santa Cruz Formation (Figs. 9a, 9c, 9d);

- 5-20\% quartz crystals (poly- to mono-crystalline) derived most probably from the Santa Cruz Formation (some may be coming from fluvio-glacial deposits) ( $\leq 2 \mathrm{~mm}$, sub-rounded) (e.g., Figs. 9c, 9d, 9e);

- 0-1\% feldspar crystals from the same source $(\leq 2 \mathrm{~mm}$, sub-rounded) (Figs. 9d, 9e);

- $5-10 \%$ olivine crystals, most of which likely represent phenocrysts of the newly erupted magma and detached crystals from mafic lithic fragments (some may be xenocrysts from the mantle) $(\leq 0.5 \mathrm{~mm}$, euhedral to subhedral) (Fig. 9e).

Additionally, a fine brownish matrix (mostly optically irresolvable) makes-up 5-25\% of the deposits. This matrix is interpreted mostly as palagonitized fine ash of juvenile origin but could include other crushed components and small particles from pre-maar sediments.

\subsection{A thick phreatomagmatic bed}

Another location worth describing separately is station PAVF-017 in the NW area of the East Maar (Fig. $3 a)$. There, the succession of palagonitized layers includes 
a $1.75 \mathrm{~m}$-thick LT bed characterized by an apparent lack of grading or internal structures (Fig. 8c) and the paucity of ash particles (Fig. 8d). The bed includes a few peridotite nodules, about 5\% sedimentary clasts, and numerous basaltic fragments, consisting of a mixture of juvenile and lithic clasts (Fig. 9f). This particular bed is thicker and better sorted than is otherwise typical of maar rim deposits in the East Maar, but its origin remains uncertain. One possibility is that it was produced by a sustained tephra fall event; another is that the eruption column was directed for a while towards this side of the maar, rather than being vertical, resulting in a thicker accumulation of pyroclasts than in other beds.

\section{The West Maar}

Dimensions for the topographic rim of the West Maar are $1.87 \mathrm{~km} \mathrm{N-S}$ by $1.90 \mathrm{~km} \mathrm{E-W}$. The rim, on which phreatomagmatic deposits are locally exposed, surrounds a broad and shallow basin (Fig. 10a), rather than a typical deep maar crater. This likely reflects modification of the original crater(s) by secondary processes. The broad and shallow aspect of the basin, with the irregular contours, could also be due in part to an assemblage of coalesced craters. This interpretation is supported by the identification of step-like semi-circular zones in the centre part of the depression. These step-like circular features can be visualized through the grass cover in the field, and commonly the steps are only a few $\mathrm{dm}$ high.

Two small shallow lakes are sometimes present in the northern part of the basin. One of these lakes, Laguna Salsa (Fig. 5d) - the only one clearly visible on Fig. 3a is located within one of two larger shallow sub-circular depressions, 500-600 m across and labelled "dried lakes". One possible interpretation is that these "dried lakes" result from continued subsidence of the underlying diatremes, in a similar fashion to what has been reported from some dry maars in the West Eifel volcanic field (Lorenz and Zimanowski, 2008) and demonstrated on Oligocene maar-diatreme successions from Saxonia (Suhr et al., 2006). This would mean that the West Maar basin does indeed represent a collection of coalesced craters.

The basin is opened to the west due to definite fluvial modification (Fig. 3a), possible eolian modification, and likely also as a result of only a little phreatomagmatic tephra being deposited there due to strong winds during the eruption.

No outcrop of comparable quality to PAVF-021 is available in the West Maar, and little can be said about the eruptive styles or depositional mechanisms for the phreatomagmatic tephra. The only location where workable outcrop exists is the SW corner of the basin, about $30 \mathrm{~m}$ above the basin floor. There, ash mantles the inner slope of the basin (Fig. 10b). The deposits are mostly unconsolidated, locally contain rim-type accretionary lapilli, and are rich in non-juvenile particles, likely derived from the underlying glacial deposits.

\section{Geochemistry}

We determined the geochemical composition of twenty samples from the PAVF, including eleven from the studied volcanic complex (Figs. 11, 12; see caption of Fig. 11 for analytical methods). Weathered crusts were removed and almost all selected samples were free of visible secondary minerals (in a few cases, $<1 \%$ secondary minerals were present in vesicles). Chosen samples included five lava flows, three bombs from magmatic explosive eruptions, and twelve single $\mathrm{cm}$-sized basaltic fragments from phreatomagmatic deposits (individually extracted with a rock saw from various tephra rim samples). The basaltic fragments from phreatomagmatic deposits ranged from grey and dense to black and vesicular, with variable phenocryst contents. The purpose of this scoping study was to see if, using geochemistry, we could determine where the basaltic lithics were coming from, and distinguish juvenile clasts from lithic fragments. Fresh sideromelane clasts were not obtainable from phreatomagmatic deposits despite our best efforts to separate them, and we did not analyze palagonitized juvenile clasts.

In general, the analyzed samples fall within, or extend, the compositional fields defined for the PAVF lavas using data from D'Orazio et al. (2000). The analyzed samples are slightly more primitive, on average, than those defining the existing compositional fields (Figs. $11 \mathrm{a}, \mathrm{b})$; they are all alkaline basalts or basanites. The two samples with total alkalis near 3\% have higher loss on ignition values than our other samples so we suspect that alteration lowered their alkali contents. All our analyses fall in the "within plate basalt" fields on tectonic discrimination diagrams (Figs. 11e, f).

Samples from the volcanic complex described here are represented by grey squares on figure 11 and are the only ones plotted individually on figure 12 . The main group of samples on figure 12 corresponds rather well with the U2 compositional field obtained from D'Orazio et al. (2000), except for slightly steeper rare earth element (REE) slopes. This main group of samples includes postmaar spatter deposits, the pre-maar lava flow at station PAVF-023 (near PAVF-025) at about $175 \mathrm{~m}$ above sea level, and several fragments in phreatomagmatic deposits from the East Maar. So it appears that the magma composition did not change significantly between the youngest pre-maar effusive eruptions and the post-maar spatter-forming activity. By interpolation, the composition of the magma responsible for the maar-type activity was also the same, and juvenile fragments cannot be geochemically distinguished from pre-maar scoria or lava clasts in the phreatomagmatic deposits.

Three samples, however, stand out from the main group (Figs. 11c, 11d, 11f, 12b). They are characterized by higher concentrations of $\mathrm{Ba}$, Th, $\mathrm{U}$, and light REE relative to samples from the main group, as well as lower $\mathrm{Ta}$ and $\mathrm{Hf}$ values. One of these outstanding samples is from an aphyric, nodule-free lava flow about $750 \mathrm{~m}$ north of the East Maar, at about $160-170 \mathrm{~m}$ above sea level (station PAVF-035, see Fig. 3a for location), i.e. a lower elevation than the lava sampled at station PAVF-023. The 
other two outstanding geochemical data points are slightly vesicular grey basaltic clasts extracted from phreatomagmatic deposits sampled in the northeast part of the East Maar at about $195 \mathrm{~m}$ above sea level (station PAVF-031). These three samples are labelled "special lava" on figures $11 \mathrm{c}-\mathrm{d}$ and 12 . Clearly the lava flow at station PAVF-035 extended further south originally; it was excavated by the maar-forming eruptions; and it is now found as grey lithic clasts in phreatomagmatic deposits of the East Maar. Other grey basaltic clasts, though, belong to the main group of samples.

This preliminary geochemical investigation suggests a potential to identify individual lava flows in lithic fragments from pyroclastic deposits in the PAVF.

\section{Discussion: maars in hard and soft substrates}

Before discussing maars emplaced in mixed substrates such as the maar complex studied in the PAVF, it will be useful to review some background information on maars emplaced in a hard vs. soft substrates, as endmember cases (Fig. 13).

\subsection{Maars in hard substrates}

Maar-diatreme volcanoes emplaced in environments where rocks dominate the shallow part of the substrate are characterized by comparatively deep cone-shaped diatremes, probably in some cases more than $1.5 \mathrm{~km}$ deep (e.g., southern African kimberlites: Clement and Reid, 1989; Field et al., 2008). The diatremes seem nearly as large as the maars on typical cross-sections (Fig. 13b). The walls of maar craters can be vertical (e.g., Joya Honda, Mexico: Aranda-Gómez and Luhr, 1996) or steeply dipping (Fig. 13a).

In the Campo de Calatrava volcanic field, Spain, the 60 hard-substrate maars measured by Martín-Serrano et al. (2009) have an average crater radius of $339 \mathrm{~m}$ and the average ratio of the short to the long axis of the craters is 0.80 (standard deviation 0.17). These figures are compared with equivalent numbers from maars in soft substrates below.

In hard substrates, the aquifer from which the external water necessary for phreatomagmatism is derived is a joint aquifer (e.g., West Eifel volcanic field: Lorenz, 1973) or a karstic system (e.g., Swabian Alb: Lorenz, 1979; Bakony Balaton Highland volcanic field: Auer et al., 2007).

Pyroclastic rocks/deposits from the tephra rim and the diatreme fill contain abundant country rock fragments: on average 80\% in the West Eifel volcanic field (Lorenz, 1986). Lake basins found in maar craters tend to be funnel-shaped as opposed to bowl-shaped (e.g., Lac Pavin, France: Juvigné et al., 1993; Campo de Calatrava: Martín-Serrano et al., 2009) (Fig. 13a).

\subsection{Maars in soft substrates}

Maar-diatreme volcanoes emplaced in environments where unconsolidated, permeable deposits dominate (soft substrates) tend to have large bowl-shaped craters, with gently dipping inner walls (Auer et al.,
2007). Lake basins in soft-substrate maars tend to be bowl-shaped as well (Fig. 13c). In many cases, the nature of the diatremes is not known, but there are examples where diatremes appear much narrower than overlying craters, and possibly not as deep as those found in hard substrates, creating "champagne glass" shapes for maardiatreme-systems in cross-section (e.g.: Ellendale, Australia: Smith and Lorenz, 1989; possibly Maegok, Korea: Kwon and Sohn, 2008; Fig. 13d).

The obvious source of water in soft-substrate maars is the pore water in the unconsolidated deposits (Lorenz, 2003). However, it is possible that some water-saturated sediments have a relatively low permeability, especially if they are fine-grained or poorly sorted. In this case, synsedimentary faults may contribute external water to fuel phreatomagmatic activity (Lorenz and Haneke, 2004; Lorenz, 2008), although muddy fault gauge is typically an aquaclude so this process would not work in muddy sediments. Another possibility to obtain magma-water interaction in a soft substrate setting is that portions of the substrate collapse into the crater or the diatreme; the collapsed domains then liberate their pore water more readily through disaggregation, even if they normally have a low permeability. Also, liquified sediments can act as "impure coolants" to fuel phreatomagmatism (White, 1991, 1996).

Sills are very common in soft substrate settings (e.g., Midland Valley basin in Scotland: Francis, 1968; Saar-Nahe basin, Germany: Lorenz, 2008) and may be contemporaneous with some maar-diatreme volcanoes. Specifically, Németh and Martin (2007) have suggested that a sill-dyke complex fed the Tátika diatreme volcano in Hungary (Fig. 13e). A natural question is: why didn't all these sills, which intruded in water-saturated sediments, form maar-diatreme volcanoes instead of sills? The most favourable place for explosive magma-water interaction and maar generation in a soft substrate setting seems to be relatively shallow in the sedimentary pile (within a few hundred meters of the surface), since this is where compaction and cementation of the sediments is the smallest and volumetric expansion of vapour is the greatest. Deeper down, permeability is progressively reduced due to compaction and cementation. Németh and Martin (2007) report that only the relatively shallow sills and dykes in the area they studied have peperitic margins, suggesting that water was less abundant deeper down in the sediment pile.

Pyroclastic rocks/deposits from the tephra rim and the diatreme fill for soft substrate maars typically contain individual grains (such as rounded quartz, feldspar, etc.) or rock pebbles from the pre-maar deposits, rather than angular rock fragments (e.g., Argyle, Australia: Boxer et al., 1989; Saar-Nahe diatremes, Germany and Midland Valley, Scotland: Lorenz, 2003, 2008, and references therein). Also, some juvenile fragments contain quartz or feldspar xenocrysts, showing that these minerals were loose before they were incorporated in the rising magma. However, the pyroclastic deposits may also contain rock 
fragments from deeper formations, especially if the layer of unconsolidated sediments in the substrate is thin.

In the Campo de Calatrava volcanic field, the 66 soft-substrate maars measured by Martín-Serrano et al. (2009) have an average crater radius of $556 \mathrm{~m}$ and the average ratio of the short to the long axis of the craters is 0.75 (standard deviation 0.16). In other words, in this volcanic field (dated at 6-1.7 Ma; J. Vegas, pers. commun., 2009), the size of the craters for soft-substrate maars is $64 \%$ larger on average than that of hard-substrate maars, but the average crater shape in map view is quite similar.

The larger average size of soft-substrate maars (at least in one volcanic field) warrants an explanation. Clearly the unconsolidated material cannot sustain vertical walls very long and the crater will growth laterally due to collapse on various scales, either during the eruption or afterwards (Sohn and Park, 2005; Pirrung et al., 2008; Martín-Serrano et al., 2009). Another explanation for large craters is lateral vent migration (Sohn and Park, 2005; Ort and Carrasco-Núñez, 2009).

\subsection{Morphologic comparison}

We have investigated whether soft-substrate maars are shallower, for a certain crater diameter, than hardsubstrate maars. According to our preliminary compilation, this does not seem to be the case. Figure 14 shows that for our limited dataset, the youngest maars of each type have diameter/depth ratios in the same range (3 to 5). Intuitively, the ratios should depend on the substrate type, since non-consolidated sediments will tend to fill the crater though mass-flow/collapse processes, etc. as the eruption proceeds and also afterwards.

It is interesting to note that it may take only a few years, after the eruption, for inner crater slopes to get much gentler in soft substrate maars, whereas the crater wall may stay vertical or very steep much longer in hard substrate maars. For example, the data points on figure 14 for the Ukinrek maars are the dimensions of the craters right after the 1977 eruption, but a site visit to Ukinrek East in 2004 showed $35^{\circ}$ inner slopes (on debris fans), and a crater diameter/depth ratio of 5.7 (up from 3.4) (Pirrung et al., 2008). The main processes that led to widening of the Ukinrek East crater and decrease in its depth are sudden collapses of the walls and the growth of debris fans. Apparently the diameter/depth ratio was already 5.2 in 1981, just four years after the eruption (Büchel and Lorenz, 1993; Pirrung et al., 2008).

Yet not all soft-substrate maars evolve this rapidly, as a counter-example is provided by Ubehebe, a softsubstrate maar that appears little modified since its formation in the Pleistocene (J.D.L. White, pers. commun., 2010).

\section{Interpretation of the studied PAVF maars}

Having reviewed the end-member cases of maars emplaced in hard vs. soft substrates, we can now look at maars found in mixed settings, including the studied
PAVF maar complex. The overall eruptive history of this volcanic complex is relatively straightforward: first, explosive eruptions dominated by phreatomagmatic activity, probably from two dyke segments, produced two juxtaposed maars; then, explosive magmatic eruptions produced scoria and spatter at a number of locations along the same E-W fissure. The topics we want to discuss here are (1) the eruptive processes for the East Maar tephra rim; (2) the environment of emplacement for the maars in the complex, which is clearly a "mixed" environment. We also compare the PAVF maar complex with other maars emplaced in mixed substrates.

\subsection{Interpretation of the East Maar tephra rim deposits}

The tephra rim beds were almost exclusively produced by phreatomagmatic activity, given the following observations: (i) they surround a typical maar crater, excavated well below the pre-eruptive surface, and form a low ring around this crater; (ii) they consistently contain several tens of percent of lithic fragments, showing again excavation into the substrate by explosive activity - this is typical of maar-diatreme volcanoes formed by phreatomagmatic explosions (Fisher and Schmincke, 1984); (iii) they contain juvenile fragments made of sideromelane (or former sideromelane), which indicates rapid cooling of magma in contact with external water (Fisher and Schmincke, 1984) or impure coolants such as wet sediment (White, 1996); (iv) many of the sideromelane particles have few or no vesicles, indicating cooling and fragmentation of rising magma due to external water before vesiculation had reached its potential; also, there is a wide range of vesicularities observed in juvenile clasts from individual tephra rim samples, which is typical of phreatomagmatic activity (e.g., Houghton and Wilson, 1989); (v) the tephra rim beds occasionally contain a few accretionary lapilli, demonstrating the presence of moisture in the eruption columns (Schumacher and Schmincke, 1995).

Since most of the studied layers from the maar tephra rim on the inner slope of the crater are very gently dipping, relatively thin and poorly sorted, and that many contain evidence for channeling into older layers or at least irregular thicknesses, as well as low-angle crossbedding, it appears that the bulk of the East Maar tephra rim was formed by a succession of pyroclastic surges, probably "dry" base surges from phreatomagmatic activity (e.g., Fisher and Waters, 1970; Crowe and Fisher, 1973; Sohn and Chough, 1989; Chough and Sohn, 1990; Valentine and Fisher, 2000).

Nevertheless, the few scoria fall layers intercalated in the palagonitized tephra rim layers may require that minor strombolian-style activity also occurred more or less simultaneously with the phreatomagmatic activity, perhaps from a different part of the same fissure, as observed for example at Ukinrek (Kienle et al., 1980; Self et al., 1980; Büchel and Lorenz, 1993)..

\subsection{Environment of emplacement for the studied maars}


"Mixed" or "combined" substrates (Lorenz, 2003) are those that contain both rocks and unconsolidated deposits. Typically the "soft" material is found above the "hard" basement (Lorenz, 2003). A more complex scenario is that the unconsolidated deposits in the substrate can be interbedded with "hard" rocks. This is clearly the case for the studied maars in the PAVF, where mafic lava flows occur on top of fluvio-glacial deposits. The pyroclastic rocks of the East Maar show that the substrate contained, from youngest to oldest: lava flows, Plio-Pleistocene fluvio-glacial deposits, the relatively soft Santa Cruz Formation, and older, better consolidated sediments. Therefore, both pore aquifers (e.g., the Santa Cruz Formation) and fracture aquifers (in the lavas) may have supplied the water to fuel the phreatomagmatic eruptions. Within the Plio-Pleistocene fluvio-glacial deposits, permeability varies greatly at a regional scale (e.g., low-permeability tills vs. very permeable gravels), but even the low-permeability sediments, if water-rich, may have fuelled the phreatomagmatism as impure coolants (White, 1991, 1996).

Since lava flow fragments, quartz particles and tillderived clasts dominate the lithic population in the LT beds, it is reasonable to infer that the near surface deposits supplied most non-juvenile fragments and that the underlying diatreme is relatively small compared to the maar crater size, which is a common feature of maars emplaced in soft substrates (see section 7.2 above).

\subsection{Other maars emplaced in mixed environments}

Interestingly, there are volcanoes, such as at the young Tecuitlapa Maar in Mexico, where the presence of relatively small thicknesses of unconsolidated deposits at the surface, on top of limestones and andesites, prevented downward penetration of explosions and instead led to lateral vent migration in the "soft" porous material (Ort and Carrasco-Núñez, 2009). The reported thickness of water-saturated non-consolidated volcaniclastic deposits (the "toba café" unit) at Tecuitlapa is "10 to $40 \mathrm{~m}$ " (Ort and Carrasco-Núñez, 2009).

In contrast, at the nearby Atexcac Maar, the same mixed pre-eruptive environment (including $24 \mathrm{~m}$ of "toba café") allowed downward penetration of the explosions so that most lithic clasts in the phreatomagmatic deposits consist of andesite or limestone (Carrasco-Núñez et al., 2007). Clearly factors other than the thickness of the unconsolidated near-surface deposits also control whether or not these deposits act as the main aquifer and locus of phreatomagmatic explosions in maar-forming eruptions. The lithological character of such deposits is an obvious control but probably cannot be invoked in the Mexican comparison. Therefore, additional factors not related to the maar substrate, such as the behaviour of the magma delivery system, must also be considered in such comparisons.

In regions where maars are emplaced in a soft substrate, a rocky basement will exist somewhere at depth, even if it is not represented by accidental fragments in the pyroclastic deposits of the maar. Depending on the thickness of the soft units and hydrologic conditions, the phreatomagmatic explosion sites may or may not penetrate into the basement units. Where the unconsolidated deposits are sufficiently thick, downward propagation of the diatreme may be limited by lowpermeability sediments at depth (Kwon and Sohn, 2008; Lorenz, 2008). In the case of thinner soft units, hydrologic conditions in the basement may dictate if the maar acquires a bowl shape (no or low penetration in the basement: essentially a soft substrate-only maar) or becomes deeper (true mixed substrate). Németh et al. (2008) discuss a Hungarian case where karst-related porosity allowed a maar-diatreme volcano to penetrate below the soft substrate.

\section{Conclusions}

The morphologic parameters, pyroclastic deposits and evolution of monogenetic volcanoes are controlled by the magma delivery system but strongly influenced by the external environment in which the magma erupts, including the nature of the substrate. In this paper, we have focused our attention on the influence of the substrate ("hard", mixed, or "soft") on maar-diatreme volcanoes. We have described a Quaternary two-maar complex in the Pali Aike volcanic field where explosive magma-water interaction took place in a mixed setting. The East Maar is better preserved than the West Maar, and its tephra rim was documented in some detail. We infer that this tephra rim, higher in the east due to strong winds during the eruption, was deposited mostly by dry pyroclastic surges from phreatomagmatic eruption columns. The pyroclastic deposits of the tephra rim contain abundant lithic fragments which, when combined with regional information on the pre-maar stratigraphy, allow us to constrain the type of substrate present at the time of the phreatomagmatic eruptions. The lithics are dominated by lava fragments from the pre-maar basaltic flows, accompanied by disaggregated Plio-Pleistocene fluvio-glacial deposits and loose particles from the poorly consolidated Miocene Santa Cruz Formation. Deeper formations of the Magallanes Basin are less represented in the lithic fragments of the East Maar tephra rim, suggesting that the diatreme underlying the East Maar narrows quickly with depth and/or is not a deep structure. If this statement is correct, then the studied volcanic complex has much in common with many maar volcanoes emplaced in a soft substrate, despite the presence of lavas at the very top of the pre-eruptive sequence.

\section{Acknowledgements}

We thank Bernd Zolitschka for discussions and support during field work in Argentina. Pierre Kliem and Frank Mueller helped with the differential GPS survey shown in figure 4. This research is partly supported by the International Continental Scientific Drilling Program (ICDP) in the framework of the Potrok Aike Maar Lake Sediment Archive Drilling Project (PASADO). Funding for PASADO is provided by the ICDP, the German Science Foundation, the Swiss National Funds, the 
Natural Sciences and Engineering Research Council of Canada (NSERC; Special Research Opportunities grant to Pierre Francus), the Swedish Vetenskapsradet and the University of Bremen. P.-S.R.'s research on maardiatreme systems is also funded in part by a Discovery Grant from NSERC. Two authors (M.H. and K.N.) acknowledge support from the TET-SECYT ArgentinaHungarian Bilateral ST Fund and the MURF research project (RM 13227). Volker Lorenz carefully read a draft of the manuscript and made many helpful comments. Journal reviewers J.D.L. White and Y.K. Sohn made many constructive suggestions which also improved the manuscript.

\section{References}

Aranda-Gómez, J.J., Luhr, J.F., 1996. Origin of the Joya Honda maar, San Luis Potosí, México. Journal of Volcanology and Geothermal Research 74, 1-18.

Aranda-Gómez, J.J., Luhr, J.F., Pier, G., 1992. The La Breña El Jagüey Maar Complex, Durango, México: I. Geological evolution. Bulletin of Volcanology 54, 393-404.

Auer, A., Martin, U., Németh, K., 2007. The Fekete-hegy (Balaton Highland Hungary) "soft-substrate" and "hardsubstrate" maar volcanoes in an aligned volcanic complex Implications for vent geometry, subsurface stratigraphy and the palaeoenvironmental setting. Journal of Volcanology and Geothermal Research 159, 225-245.

Biddle, K.T., Uliana, M.A., Mitchum, R.M., Fitzgerald, M.G., Wright, R.C., 1986. The stratigraphic and structural evolution of the central and eastern Magallanes basin, southern South America. In: Allen, P.A., Homewood, P. (Editors), Foreland Basins. International Association of Sedimentology, Special Publication 8, pp. 41-61.

Blisniuk, P.M., Stern, L.A., Chamberlain, C.P., Idleman, B., Zeitler, P.K., 2005. Climatic and ecologic changes during Miocene surface uplift in the Southern Patagonian Andes. Earth and Planetary Science Letters 230, 125-142.

Boivin, P., Bourdier, J.L., Camus, G., de Goer de Herve, A., Gourgaud, A., Kieffer, G., Mergoil, J., Vincent, P.M., Auby, R., 1982. Influence de la nature des magmas sur l'activité phréatomagmatique: approche volcanologique et thermodynamique Bulletin Volcanologique 45, 25-39.

Boxer, G.L., Lorenz, V., Smith, C.B., 1989. The geology and volcanology of the Argyle (AK1) lamproite diatreme, Western Australia. In: In: Ross, J., Jaques, A.L., Ferguson, J., Green, D.H., O'Reilly, S.Y., Danchin, R.V., Janse, A.J.A. (Editors), Kimberlites and Related Rocks. Geological Society of Australia, Special Publication 14, pp. 140-152.

Bozon, P., 1963. Contribution à l'étude des formes volcaniques de l'Ardèche. Revue de géographie alpine 51, 591-674.

Büchel, G., 1993. Maars of the Westeifel, Germany. In: Negendank, J.F.W., Zolitschka, B. (Editors.), Paleolimnology of European Maar Lakes. Lecture Notes in Earth Sciences 49, pp. 1-13.

Büchel, G., Lorenz, V., 1993. Syn- and post-eruptive mechanism of the alaskan Ukinrek maars in 1977. In: Negendank J.F.W., Zolitschka, B. (Editors), Paleolimnology of European Maar Lakes. Lecture Notes in Earth Sciences 49, pp. 15-60.

Carrasco-Núñez, G., Ort, M.H., Romero, C., 2007. Evolution and hydrological conditions of a maar volcano (Atexcac crater, Eastern Mexico). Journal of Volcanology and Geothermal Research 159, 179-197.

Clement, C.R., Reid, A.M., 1989. The origin of kimberlite pipes: An interpretation based on a synthesis of geological features displayed by southern African occurrences. In: Ross, J., Jaques, A.L., Ferguson, J., Green, D.H., O'Reilly, S.Y., Danchin, R.V., Janse, A.J.A. (Editors), Kimberlites and related rocks. Geological Society of Australia, Special Publication 14, pp. 632-646.

Chough, S.K. and Sohn, Y.K., 1990. Depositional mechanics and sequences of base surges, Songaksan tuff ring, Cheju Island, Korea. Sedimentology, 37: 1115-1135.

Corbella, H., 2002. El campo volcano-tectonico de Pali Aike. In: Haller, M.J. (Editor), Geologia y Recursos Naturales de Santa Cruz, XV Congreso Geologico Argentino, El Calafate, pp. 285-301

Corbella, H., Lara, L.E., 2008. Late Cenozoic Quaternary volcanism in Patagonia and Tierra del Fuego. In: Rabassa, J. (Editor), The Late Cenozoic of Patagonia and Tierra del Fuego. Developments in Quaternary Science 11, pp. 95119.

Corbella, H., Fey, M., Haberzettl, T., Mayr, C., Ohlendorf, C., Wille, M., Zolitschka, B., 2009a. Potrok Aike, a peculiar maar among the one hundred phreatomagmatic edifices, Pali Aike Volcanic Field, southern Patagonia, Argentina. Third International Maar Conference, Malargüe, Argentina, April 2009, Abstracts, pp. 19-20.

Corbella, H., Ercolano, B., Tiberi, P., 2009b. Laguna Azul: a unique lagoon in Pali Aike Holocene eruptive terrains, Patagonia Austral, Argentina. Third International Maar Conference, Malargüe, Argentina, April 2009, Abstracts, p. 17-18.

Crowe, B.M., Fisher, R.V., 1973. Sedimentary structures in base-surge deposits with special reference to cross-bedding, Ubehebe Craters, Death Valley, California. Geological Society of America Bulletin 84, 663-682.

Dawson, J.B., Powell, D.G., 1969. The Natron-Engaruka explosion crater area, northern Tanzania. Bulletin Volcanologique 33, 791-817.

de Ignacio, C., López, I., Oyarzun, R., Márquez, A., 2001. The northern Patagonia Somuncura plateau basalts: a product of slab-induced, shallow asthenospheric upwelling? Terra Nova 13, 117-121.

Diraison, M., Cobbold, P.R., Gapais, D., Rossello, E.A., 1997. Magellan Strait: part of a Neogene rift system. Geology 25, 703-706.

D'Orazio, M., Agostini, S., Mazzarini, F., Innocenti, F., Manetti, P., Haller, M.J., Lahsen, A., 2000. The Pali Aike Volcanic Field, Patagonia: slab-window magmatism near the tip of South America. Tectonophysics 321, 407-427.

Field, M., Stiefenhofer, J., Robey, J., Kurszlaukis, S., 2008. Kimberlite-hosted diamond deposits of southern Africa: a review. Ore Geology Reviews 34, 33-75.

Fisher, R.V. and Waters, A.C., 1970. Base surge forms in maar volcanoes. American Journal of Science, 268: 157-180.

Fisher, R.V., Schmincke, H.-U., 1984. Pyroclastic Rocks. Springer-Verlag, Berlin, $472 \mathrm{pp}$.

Francis, E.H., 1968. Effect of sedimentation on volcanic processes, including sill-neck relationships, in the British Carboniferous. 23 ${ }^{\text {rd }}$ Geological Congress, pp. 163-174.

Gutmann, J.T., 1976. Geology of Crater Elegante, Sonora, Mexico. Geological Society of America Bulletin 87, 17181729.

Haller, M.J., Nemeth, K., 2006. Architecture and pyroclastic succession of a small Quaternary (?) maar in the Pali Aike 
Volcanic Field, Santa Cruz, Argentina. Zeitschrift der Deutschen Gesellschaft für Geowissenschaften 157, 467476.

Haller, M.J., de Wall, H., Martin, U., Nemeth, K., 2006. Understanding the evolution of maar craters, ICDPWorkshop PASADO, Potrok Aike Lake Sediment Archive Drilling Project, Terra Nostra 2006-1, p. 58.

Houghton, B.F., Schmincke, H.-U., 1986. Mixed deposits of simultaneous Strombolian and phreatomagmatic volcanism: Rothenberg volcano, East Eifel volcanic field. Journal of Volcanology and Geothermal Research 30, 117-130.

Houghton, B. and Wilson, C.J.N., 1989. A vesicularity index for pyroclastic deposits. Bulletin of Volcanology, 51: 451-462.

Houghton, B.F., Wilson, C.J.N., Smith, I.E.M., 1999. Shallowseated controls on styles of explosive basaltic volcanism: a case study from New Zealand. Journal of Volcanology and Geothermal Research 91: 97-120.

Irvine, T.N., Baragar, W.R.A., 1971. A guide to the chemical classification of common volcanic rocks. Canadian Journal of Earth Sciences 8, 523-548.

Juvigné, E., Camus, G., de Goër de Herve, A., 1993. Maars of northern Auvergne (Massif Central, France): state of knowledge. In: Negendank, J.F.W., Zolitschka, B. (Editors), Paleolimnology of European Maar Lakes. Lecture Notes in Earth Sciences 49: 81-94.

Kienle, J., Kyle, P.R., Self, S., Motyka, R., Lorenz, V., 1980. Ukinrek Maars, Alaska, I. Eruption sequence, petrology and tectonic setting. Journal of Volcanology and Geothermal Research 7, 11-37.

Kjarsgaard, B.A., 2007. Kimberlite diamond deposits. In: Goodfellow, W.D. (Editor), Mineral deposits of Canada: a synthesis of major deposits types, district metallogeny, the evolution of geological provinces, and exploration methods. Geological Association of Canada, Mineral Deposits Division, Special Publication 5, pp. 245-272.

Kwon, C.W. and Sohn, Y.K., 2008. Tephra-filled volcanic neck (diatreme) of a mafic tuff ring at Maegok, Miocene Eoil Basin, SE Korea. Geosciences Journal 12, 317-329.

Le Maitre, R.W., 1989. A classification of igneous rocks and glossary of terms. Blackwell, Oxford, $193 \mathrm{pp}$.

Lorenz, V., 1975. Formation of phreatomagmatic maar-diatreme volcanoes and its relevance to kimberlite diatremes. Physics and Chemistry of the Earth 9, 17-27.

Lorenz, V., 1979. Phreatomagmatic origin of the olivine melilitite diatremes of the Swabian Alb, Germany. In: Boyd, F.R., Meyer, H.O.A. (Editors), Kimberlites, Diatremes and Diamonds: their Geology, Petrology and Geochemistry. American Geophysical Union, Washington, pp. 354-363.

Lorenz, V., 1986. On the growth of maars and diatremes and its relevance to the formation of tuff rings. Bulletin of Volcanology 48, 265-274.

Lorenz, V., 1987. Phreatomagmatism and its relevance. Chemical Geology 62, 149-156.

Lorenz, V., 2003. Maar-diatreme volcanoes, their formation, and their setting in hard-rock and soft-rock environments. Geolines 15, 72-83.

Lorenz, V., 2008. Explosive maar-diatreme volcanism in unconsolidated water-saturated sediments and its relevance for diamondiferous pipes. Zeitschrift der Deutschen Gemmologischen Gesellschaft 57, 41-60.

Lorenz, V., Haneke, J., 2004. Relationship between diatremes, dykes, sills, laccoliths, intrusive-extrusive domes, lava flows, and tephra deposits with unconsolidated watersaturated sediments in the late Variscan intermontane Saar-
Nahe Basin, SW Germany. In: Breitkreuz, C., Petford, N. (Editors), Physical geology of high-level magmatic systems. Geological Society, London, Special Publication 234, 75-124.

Lorenz, V., Zimanowski, B., 2008. Volcanology of the West Eifel maars and its relevance to the understanding of kimberlite pipes [fieldtrip guidebook]. Ninth International Kimberlite Conference, Frankfurt am Main, Germany, 84 pp.

McClintock, M., Ross, P.-S. and White, J.D.L., 2009. The importance of the transport system in shaping the growth and form of kimberlite volcanoes. Lithos, in press (DOI: 10.1016/j.lithos.2009.04.014).

McDonough, W.F. and Sun, S.-S., 1995. The composition of the Earth. Chemical Geology, 120: 223-253.

Martín-Serrano, A., Vegas, J., García-Cortés, A., Galán, L., Gallardo-Millán, J.L., Martín-Alfageme, S., Rubio, F.M., Ibarra, P.I., Granda, A., Pérez-González, A., García-Lobón, J.L. 2009. Morphotectonic setting of maar lakes in the Campo de Calatrava Volcanic Field (Central Spain, SW Europe). Sedimentary Geology 222, 52-63.

Mazzarini, F., D'Orazio, M., 2003. Spatial distribution of cones and satellite-detected lineaments in the Pali Aike Volcanic Field (southernmost Patagonia): insights into the tectonic setting of a Neogene rift system. Journal of Volcanology and Geothermal Research 125, 291-305.

Muller, G., Veyl, G., 1956. The birth of Nilahue, a new maar type volcano at Rininahue, Chile, $20^{\text {th }}$ International Geological Congress, Mexico-City, Rept. Sec. 1, pp. 375396.

Muñoz, J., Troncoso, R., Duhart, P., Crignola, P., Farmer, L., Stern, C., 2000. The Mid-Tertiary coastal magmatic belts in south-central Chile $\left(36-43^{\circ} \mathrm{S}\right)$ : it's relation to crustal extension, mantle upwelling and the late Oligocene increase in the rate of oceanic plate subduction beneath South America. Revista Geológica Chilena 27, 177-203.

Németh, K., Martin, U., 2007. Shallow sill and dyke complex in western Hungary as a possible feeding system of phreatomagmatic volcanoes in "soft-rock" environment. Journal of Volcanology and Geothermal Research 159, 138152.

Németh, K., Goth, K., Martin, U., Csillag, G., Suhr, P., 2008. Reconstructing paleoenvironment, eruption mechanism and paleomorphology of the Pliocene Pula maar (Hungary). Journal of Volcanology and Geothermal Research 177, 441456.

Noll, H., 1967. Maare und maar-ähnliche Explosionskrater in Island, Ein Vergleich mit dem Maar-Vulkanismus der Eifel. Sonderveröffentlichungen des Geologischen Institutes der Universität Köln, 11. Köln, Germany, 117 p.

Nullo, F.E., Combina A.M., 2002. Sedimentitas Terciarias Continentales. In: Haller, M.J (Editor), Geologia y Recursos Naturales de Santa Cruz, XV Congreso Geologico Argentino, El Calafate, I: 245-258.

Ort, M.H., Carrasco-Núñez, G., 2009. Lateral vent migration during phreatomagmatic and magmatic eruptions at Tecuitlapa Maar, east-central Mexico. Journal of Volcanology and Geothermal Research 181, 67-77.

Pankhurst, R.J., Leat, P.T., Sruoga, P., Rapela, C.W., Márquez, M., Storey, B.C., Riley, T.R., 1998. The Chon Aike province of Patagonia and related rocks in West Antarctica: a large silicic igneous province. Journal of Volcanology and Geothermal Research 81, 113-136.

Pardo, N., Avellán, D.R., Macías, J.L., Scolamacchia, T., Rodríguez, D., 2008. The 1245 yr BP Asososca maar: new 
advances on recent volcanic stratigraphy of Managua (Nicaragua) and hazard implications. Journal of Volcanology and Geothermal Research 176, 493-512.

Pearce, J.A., Cann, J.R., 1973. Tectonic setting of basic volcanic rocks determined using trace element analyses. Earth and Planetary Science Letters 19, 290-300.

Pearce, J.A., 1996. A user's guide to basalt discrimination diagrams. In: Wyman, D.A. (Editor), Trace element geochemistry of volcanic rocks: applications for massive sulphide exploration. Geological Association of Canada, Short Course Notes 12, 79-113.

Pirrung, M., Büchel, G., Lorenz, V., Treutler, H.-C., 2008. Posteruptive development of the Ukinrek East Maar since its eruption in 1977 A.D. in the periglacial area of south-west Alaska. Sedimentology 55, 305-334.

Ramos, V.A., 1989. Andean Foothills structures in northern Magallanes Basin, Argentina. American Association of Petroleum Geologists Bulletin 73, 887-903.

Ramos, V.A., Kay, S.M., 1992. Southern Patagonian plateau basalts and deformation: backarc testimony of ridge collisions. Tectonophysics 205, 261-282.

Schumacher, R. and Schmincke, H.-S., 1995. Models for the origin of accretionary lapilli. Bulletin of Volcanology, 56: 626-639.

Self, S., Kienle, J., Huot, J.-P., 1980. Ukinrek Maars, Alaska II. Deposits and formation of the 1977 craters. Journal of Volcanology and Geothermal Research 7, 39-65.

Skewes, M.A., Stern, C.R., 1979. Petrology and geochemistry of alkali basalts and ultramafic inclusions from the Palei-Aike volcanic field in Southern Chile and the origin of the patagonian plateau lavas. Journal of Volcanology and Geothermal Research 6, 3-25.

Smith, C.B., Lorenz, V., 1989. Volcanology of the Ellendale lamproite pipes, Western Australia. In: Ross, J. (Editor), Kimberlites and related rocks. Geological Society of Australia, Special publication 14, pp. 505-519.

Sohn, Y.K., Chough, S.K., 1989. Depositional processes of the Suwolbong tuff ring, Cheju Island (Korea). Sedimentology 36, 837-855.

Sohn, Y.K., 1996. Hydrovolcanic processes forming basaltic tuff rings and cones on Cheju Island, Korea. Geological Society of America Bulletin 108, 1199-1211.

Sohn, Y.K., Park, K.H., 2005. Composite tuff ring/cone complexes in Jeju Island, Korea: possible consequences of substrate collapse and vent migration. Journal of Volcanology and Geothermal Research 141, 157-175.
Suhr, P., Goth, K., Lorenz, V., 2006. Long lasting subsidence and deformation in and above maar-diatreme volcanoes - a never ending story. Zeitschrift der Deutschen Gesellschaft für Geowissenschaften 157, 491-511.

Sun, S.-S., McDonough, W.F., 1989. Chemical and isotopic systematics of oceanic basalts: implications for mantle composition and processes. In: Saunders, A.D., Norry, M.J. (Editors), Magmatism in the ocean basins. Geological Society, London, Special Publication 42, 313-345.

Tyrrell, G.W., 1932. The basalts of Patagonia. Journal of Geology 40, 374-383.

Valentine, G.A. and Fisher, R.V., 2000. Pyroclastic surges and blasts. In: H. Sigurdsson, B. Houghton, S.R. McNutt, H. Rymer and J. Stix (Editors), Encyclopedia of Volcanoes. Academic Press, London, pp. 571-580.

Wang, J., Hattori, K.H., Li, J., Stern, C.R., 2008. Oxidation state of Paleozoic subcontinental lithospheric mantle below the Pali Aike volcanic field in southernmost Patagonia. Lithos 105, 98-110.

White, J.D.L., 1991. Maar-diatreme phreatomagmatism at Hopi Buttes, Navajo Nation (Arizona), USA. Bulletin of Volcanology 53, 239-258.

White, J.D.L., 1996. Impure coolants and interaction dynamics of phreatomagmatic eruptions. Journal of Volcanology and Geothermal Research 74, 155-170.

Wood, C.A., 1974. Reconnaissance geophysics and geology of the Pinacate craters, Sonora, Mexico. Bulletin Volcanologique 38, 149-172.

Wood, D.A., 1980. The application of a Th-Hf-Ta diagram to problems of tectonomagmatic classification and to establishing the nature of crustal contamination of basaltic lavas of the British Tertiary Volcanic Province. Earth and Planetary Science Letters 50, 1-30.

Zilli, N., Pedrazzini, M., Peroni G., 2002. La Cuenca Austral. In: Haller, M.J. (Editor), Geologia y Recursos Naturales de Santa Cruz, XV Congreso Geologico Argentino, El Calafate, III-3, pp. 607-662.

Zolitschka, B., Schäbitz, F., Lücke, A., Corbella, H., Ercolano, B., Fey, M., Haberzettl, T., Janssen, S., Maidana, N., Mayr, C., Ohlendorf, C., Oliva, G., Paez, M.M., Schleser, G.H., Soto, J., Tiberi, P., Wille, M., 2006. Crater lakes of the Pali Aike Volcanic Field as key sites for paleoclimatic and paleoecological reconstructions in southern Patagonia, Argentina. Journal of South American Earth Sciences 21, 294-309.

\section{FIGURES}

Fig. 1. Schematic tectonic setting of southern South America and adjacent Pacific Ocean, showing the location of the Pali Aike Volcanic Field (PAVF). Modified from D'Orazio et al. (2000), with the thickness of the infill in the Magallanes Basin taken from Ramos (1989).

Fig. 2. Geological map of the PAVF and vicinity.

Fig. 3. Aerial photos and map of the volcanic complex hosting Laguna Del Ruido and Laguna Salsa. (a) Mosaic of aerial photographs taken by one of the authors (H.C.), with superimposed unpaved roads, geological field stations, survey stations, and trace of topographic profile A-A' (see Fig. 4). Note the layering of pyroclastic deposits visible in places near the top of the inner slopes of the maar craters. (b) Schematic volcanological map.

Fig. 4. Topographic profile A-A' through the East Maar, based on a differential GPS survey (crosses on Fig. 3a and dots on the profile). Note the vertical exaggeration. A basaltic lava flow, marked "B", crops out near the top of the inner slope, on 
the south side of the East Maar. The lava is covered by palagonitized phreatomagmatic deposits. The top of this lava flow, inferred to represent the local pre-eruptive surface relative to the maar-forming eruptions, was $72 \mathrm{~m}$ higher than the lake level on October 25, 2008. Therefore after the eruption, the crater was more than $72 \mathrm{~m}$-deep relative to the pre-existing ground surface. The base of the phreatomagmatic deposits is not clear on the NE side of the crater, but preserved pyroclastic deposits are thicker and begin at lower elevations than on the south side. Abbreviations: m.a.s.l. = meters above sea level.

Fig. 5. Field photographs from the studied volcanic complex in the Pali Aike Volcanic Field. (a) Panorama of the East Maar looking south from the northernmost point on the topographic rim. (b) Overview of the pre-maar sequence at PAVF-025 (see text for descriptive information and Fig. 3a for location). (c) Close-up view of the $70 \mathrm{~cm}$-thick scoria fall deposit in the pre-maar sequence. (d) Remnants of a crescent-shape scoria and spatter accumulation (arrows) in the West Maar, looking about SE from across Laguna Salsa. (e) Detail of a post-maar clastogenic basalt outcrop in the West Maar (see text for details) showing numerous oval-shaped olivine-rich mantle nodules (arrows). (f) Part of the welded spatter deposit overlying the phreatomagmatic deposits in the NW corner of the East Maar. Note the large fluidal bombs. (g) An isolated clast of glacial till within the post-maar spatter deposit on the NW side of the East Maar. The till fragment contains grey to white rounded pebble- and sand-size particles in a fine matrix with a beige colour.

Fig. 6. Detailed log of the best phreatomagmatic outcrop (PAVF-021) in the East Maar. For outcrop location see Fig. 3a. Dashed lines represent diffuse plane-parallel layering. Dots (large and small) and uncoloured clasts collectively represent undifferentiated pyroclasts in phreatomagmatic beds. Only two beds were produced by 'magmatic' eruptions in the logged sequence, and these consist of scoria fall deposits (coloured clasts). Letters in bolded italics show the position of samples.

Fig. 7. Field photographs from the best phreatomagmatic outcrop (PAVF-021) in the East Maar. (a) General view of the outcrop. (b) Part of the basal portion of the logged sequence, showing the alternating lapilli-tuff (LT) and coarse tuff beds. (c)-(d) Close-up views of some LT beds featuring small palagonitized juvenile lapilli (J) and an assortment of lithic lapilli: lava from pre-maar flows $(\mathbf{L})$; rounded pebbles from glacial deposits $(\mathbf{P})$; and various sandstones and siltstones from the underlying sedimentary basin (S). (e) Reddish fragment, broken open with a hammer, presumed to be from the Tobífera Formation. The clast is about $10 \mathrm{~cm}$ wide. (f) Good example of an accretionary lapillus (A) in a fine LT bed which also includes a few individual olivine grains $(\mathbf{O})$.

Fig. 8. More field photographs from the East Maar: (a)-(b) from PAVF-021 and (c)-(d) from PAVF-017 (see Figure 3 for outcrop locations). (a) Tuff beds intercalated in LT beds from the lower part of the sequence. Note the low-angle crossstratification in the fine-grained package above the hammer head. (b) A channel has been cut into a succession of thin tuff beds, and then filled by LT. (c) General view of the $1.75 \mathrm{~m}$-thick LT bed interpreted as a pyroclastic fall deposit. (d) Closeup view showing the abundance of juvenile clasts (orange) and mafic lithic clasts including dense lava and scoria (black) in a zeolite cement not quite filling the primary porosity of the deposit. Note the near lack of sedimentary lithics and of a fine matrix in this bed.

Fig. 9. Photomicrographs from the East Maar showing the diversity of particles and grain sizes, including vesicular, olivinephyric juvenile fragments $(\mathbf{J})$, in which the glass is mostly altered to palagonite and clays; lithic basalt clasts $(\mathbf{L})$, many of which are olivine-phyric and with variable vesicularity and textures; individual olivine grains $(\mathbf{O})$; quartz grains $(\mathbf{Q})$; and sedimentary rocks $(\mathbf{S})$. The particles are held together by a natural cement of zeolites $(\mathbf{Z})$ and by blue glue $(\mathbf{G})$. Sample numbers: (a)-(b) PAVF-021e; (c) PAVF-021a; (d) PAVF-021b; (e) PAVF-021f; (f) PAVF-017.

Fig. 10. Photographs of the West Maar. (a) View of the southern "dried lake" taken from the crescent-shaped accumulation of scoria and spatter in the middle of the basin (see Fig. 3). Just below the horizon, some tan-coloured phreatomagmatic deposits are visible among the grass in the tephra rim. (b) Phreatomagmatic deposits in the SW part of the maar.

Fig. 11. Geochemistry of some newly analyzed Pali Aike volcanic field (PAVF) rocks, including the studied volcanic complex. (a) Total alkali-silica (TAS) diagram after Le Maitre (1989), with the subalkaline-alkaline division from Irvine and Baragar (1971). (b) $\mathrm{MgO}$ vs. $\mathrm{SiO}_{2}$ diagram. (c) $\mathrm{La}$ vs. $\mathrm{Zr}$ diagram. (d) Th vs. Yb diagram. (e)-(f) Tectonic discrimination diagrams from Pearce and Cann (1973) and Wood (1980) (with field labels from Pearce, 1996: MORB = mid-ocean ridge basalt; $\mathrm{VAB}=$ volcanic arc basalt; $\mathrm{WPB}=$ within plate basalt). Shaded areas represent PAVF rocks regionally (units U1 to U3) based on D'Orazio et al. (2000): (a) redrawn from their figure 4; (b)-(d) and (f) compiled from their table 1. The element ' $\mathrm{Y}$ ' is not listed in this table so there is no regional field shown in (e). New data is from the INRSETE geochemical laboratory in Quebec City: major elements by ICP-AES, illustrated trace elements by fusion ICP-MS. See text for discussion.

Fig. 12. Multi-element plots for rocks from the studied volcanic complex (lines). Fields from D'Orazio et al. (2000) for units U1 and U2 of the Pali Aike volcanic field are also shown (compiled from their table 1). (a) Rare earth element diagram 
with normalizing values from McDonough and Sun (1995). (b) Extended multi-element diagram with normalizing values from Sun and McDonough (1989). New data obtained at INRS-ETE by ICP-AES (Ba, Ti) and fusion ICP-MS (other elements shown). See text for discussion.

Fig. 13. Comparison of maar-diatreme systems in hard substrates (a-b) and soft substrates (c-d-e). (a) \& (c) Schematic cross-sections of the upper part of the system from the Campo de Calatrava volcanic field, Spain, redrawn and simplified from Martín-Serrano et al. (2009). (b) Typical schematic cross-section of the full maar-diatreme system after Lorenz and Zimanowski (2008). (d) North-south section through the Ellendale 9 lamproite pipe in Australia, showing the typical "champagne glass" shape of maar-diatreme systems in soft substrates, after Smith and Lorenz (1989). The Permian sands of the Grant Group were unconsolidated at the type of volcanism, and the post-maar coherent lamproite phases are filling the crater. Diamond drill holes are indicated. (e) A sill-dyke complex emplaced in sediments is interpreted to have fed the Tátika diatreme volcano in Hungary; redrawn from Németh and Martin (2007).

Fig. 14. Preliminary literature compilation of maar depths and diameters for a number of Quaternary maars. The quoted diameter in most compiled sources must be that of the tephra rim (this is not always obvious). For elliptical maars we have averaged the long and short axes of horizontal crater dimensions to calculate a typical "diameter". When possible, the depth of the crater soon after the eruption (rim crest to crater bottom) as been used for each maar (e.g. Ukinrek), but in most cases the plotted depth reflects some level of post-eruptive filling of the crater and/or erosion of the tephra rim. The youngest craters have diameter/depth ratios between 3 and 7 (dashed lines). Data sources: Asososca (Nicaragua) - Pardo et al. (2008); Atexcac (Mexico) - Carrasco-Núñez et al. (2007); Eledoi (Tanzania) - Dawson and Powell (1969); Elegante and Molina North (Mexico) - Wood (1974) and Gutmann (1976); Gour de Tazenat, Lac D'issarlès and Lac Pavin (France) - crater dimensions from Noll (1967), country rock descriptions from Juvigé et al. (1993), Bozon (1963) and Boivin et al. (1982), respectively; Joya Honda (Mexico) - Aranda-Gómez and Luhr (1996); Nilahue (Chile) - Muller and Veyl (1956); PAVF East Maar - this study; Tecuitlapa (Mexico) - Ort and Carrasco-Núñez (2009); Ubehebe (California, USA) - Crowe and Fisher (1973); Ukinrek West and Ukinrek East (Alaska) - Kienle et al. (1980); hard substrate maars from the West Eifel volcanic field (Germany) - Büchel (1993). In the West Eifel, as in other volcanic fields, older maars tend to be shallower than young maars for a certain diameter, due to erosion. 


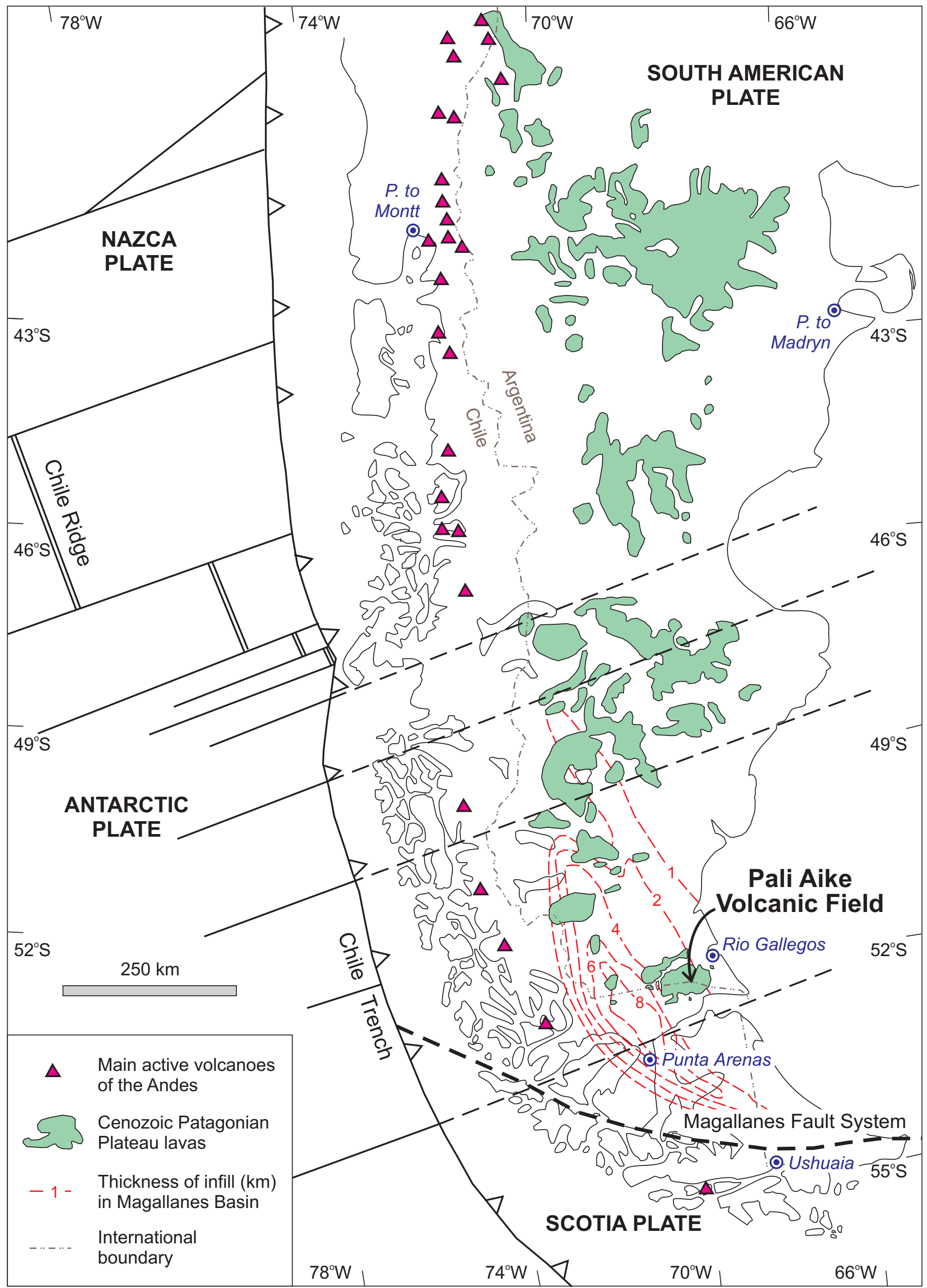




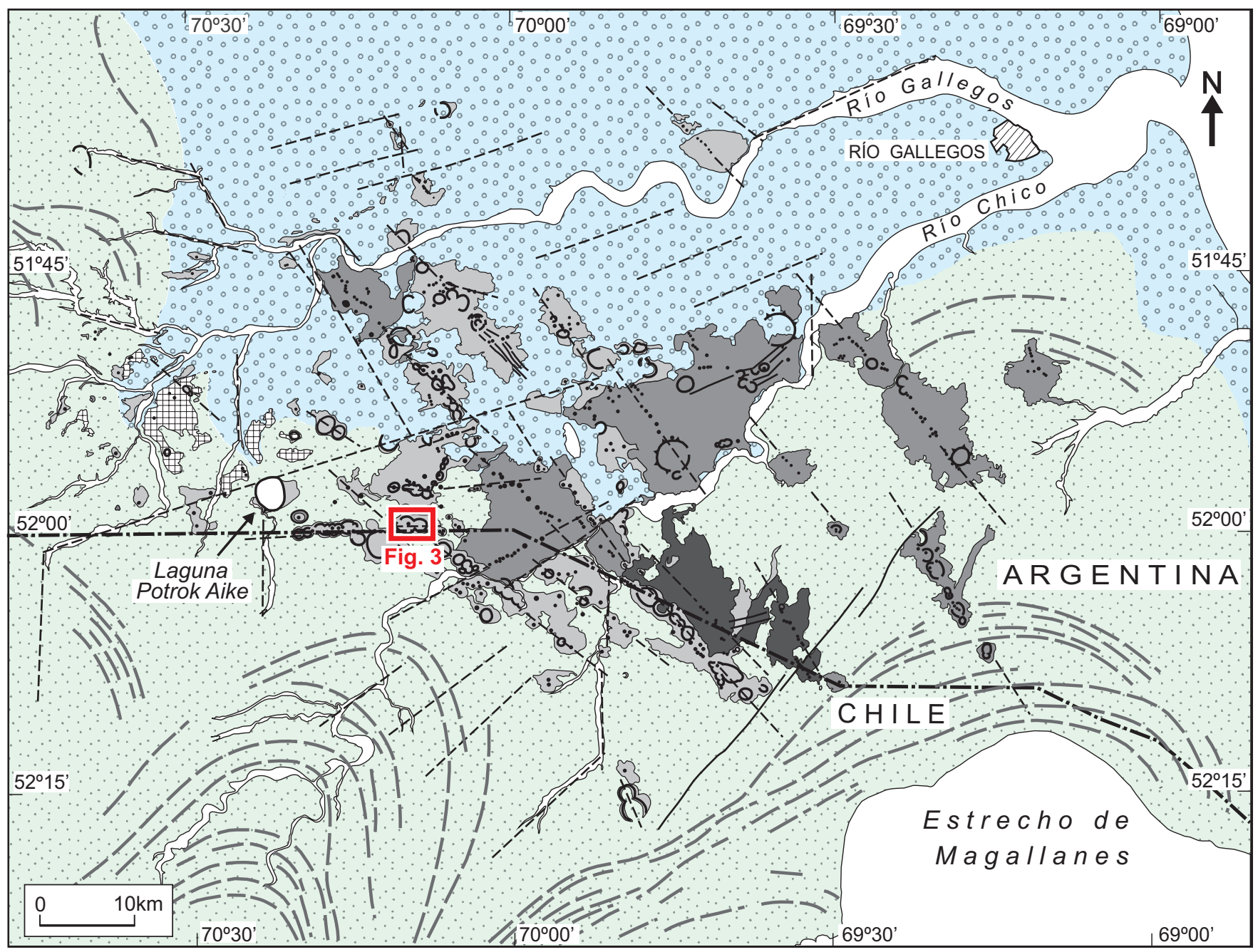

\begin{tabular}{|c|c|c|c|}
\hline \multirow{2}{*}{$\begin{array}{l}\text { Alkaline mafic volcanics, Pliocene } \\
\text { to (?)Holocene }\end{array}$} & Subalkaline mafic volcanics & $\bullet$ & Scoria and spatter cones \\
\hline & Miocene, heavily eroded & 0 & Maars \\
\hline Youngest ("Basaltos del Diablo") & ("Basaltos Bella Vista") & $n$ & Crvptodomes \\
\hline Slightly degraded and eroded & Sediments & & \\
\hline & Glacial and fluvio-glacial & $=$ & Fractures and tectonic alignments \\
\hline & O Miocene-Holocene fluvial & & Morainic ridge \\
\hline
\end{tabular}



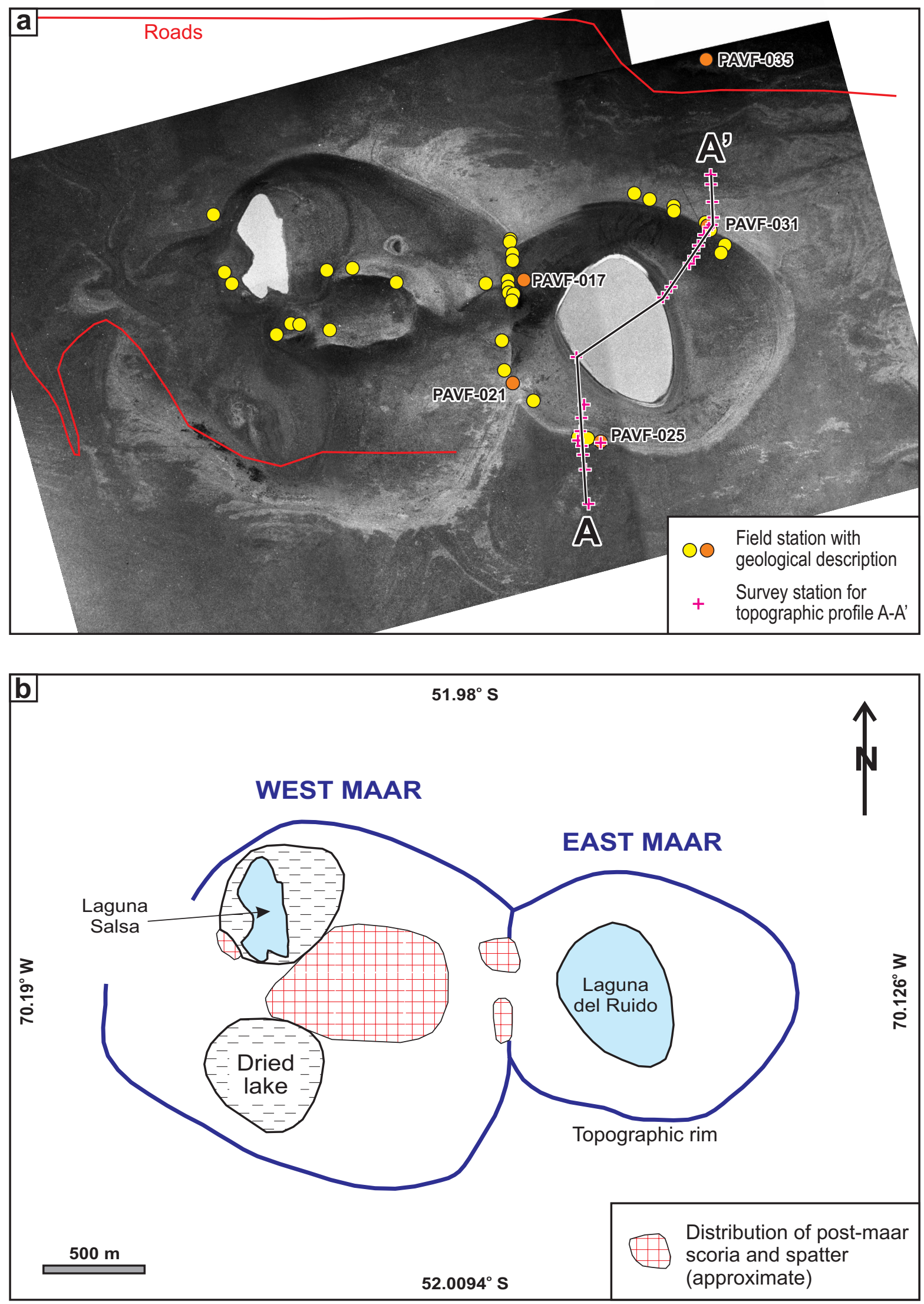


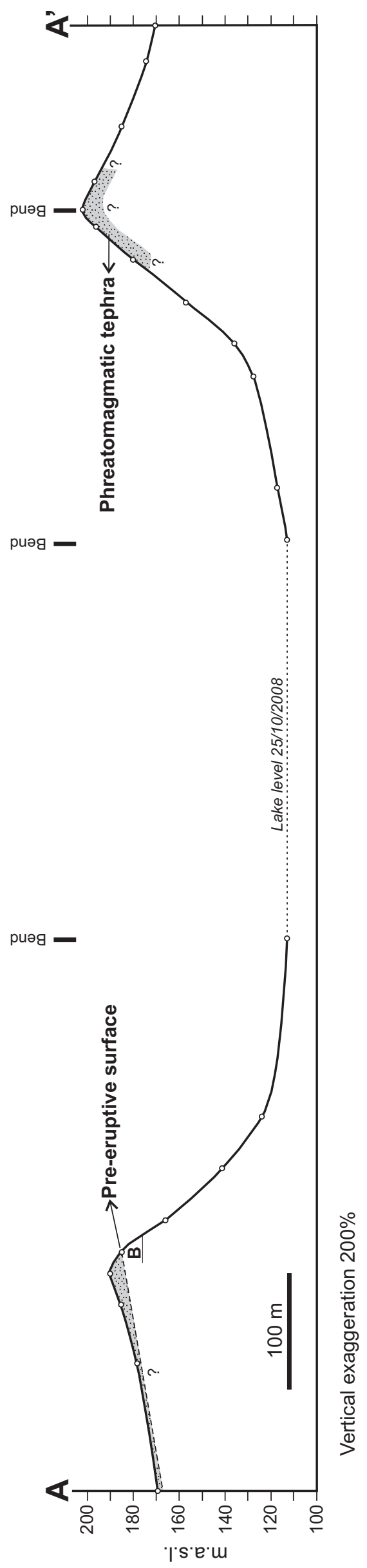

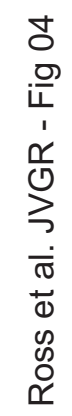



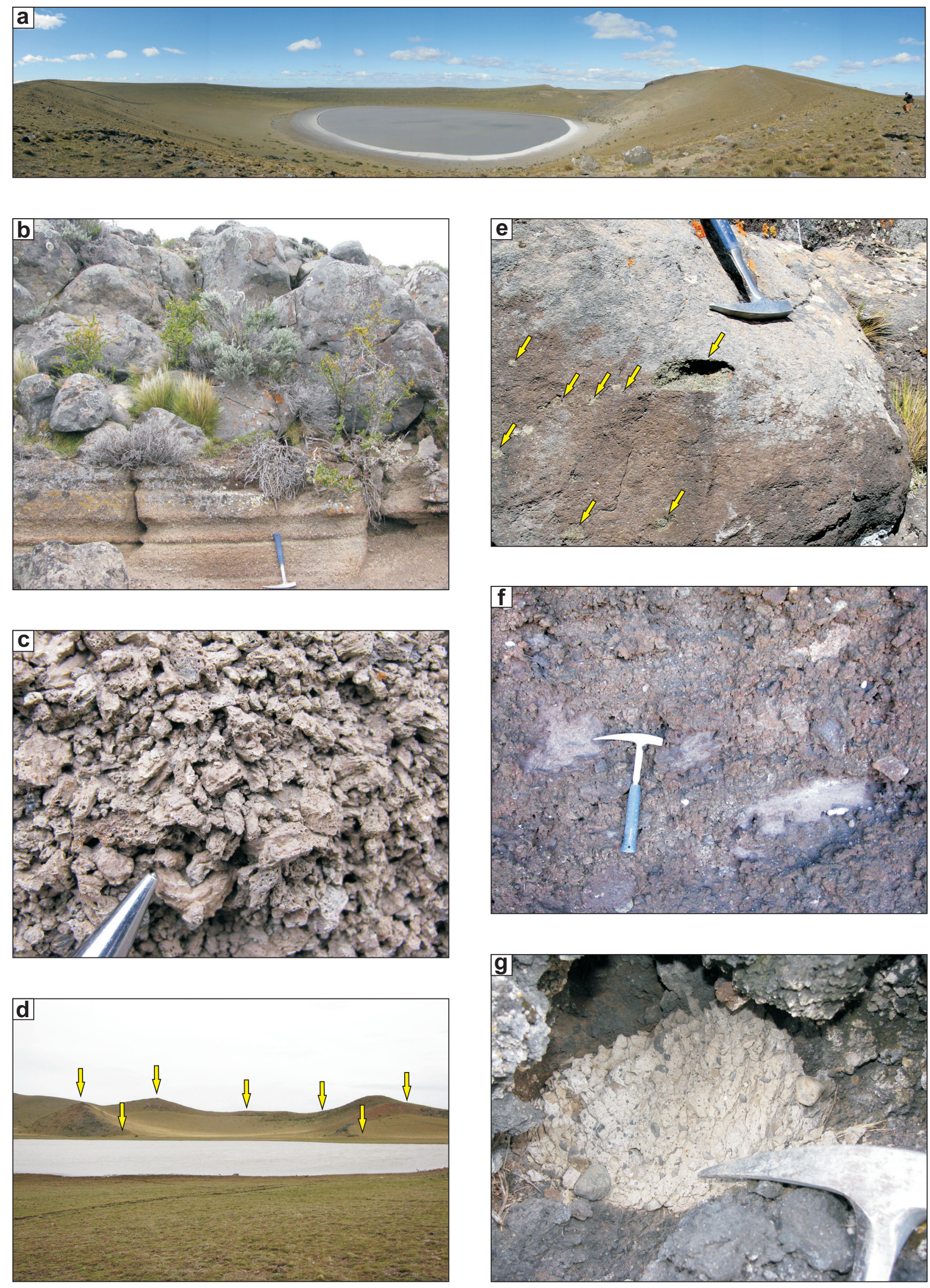


\section{CONTINUED RIGHT}

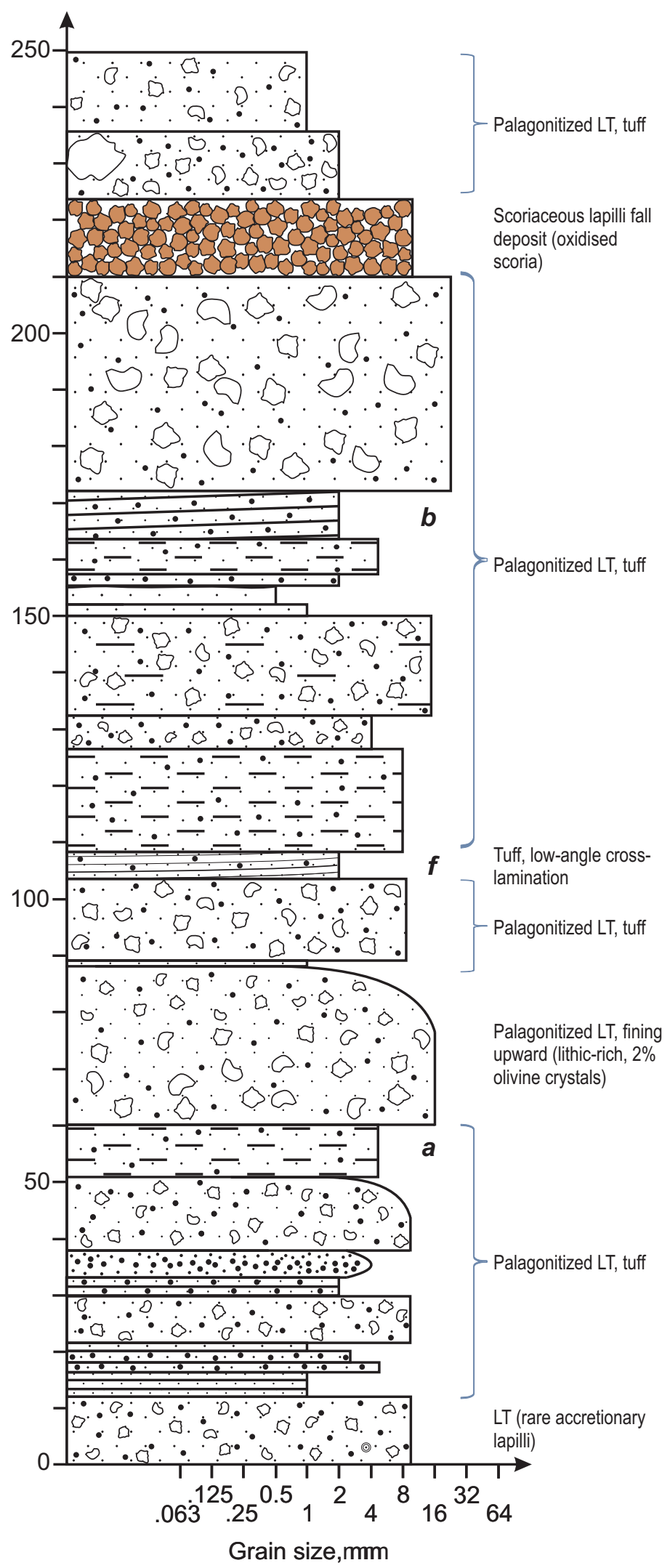

Height, $\mathrm{cm}$
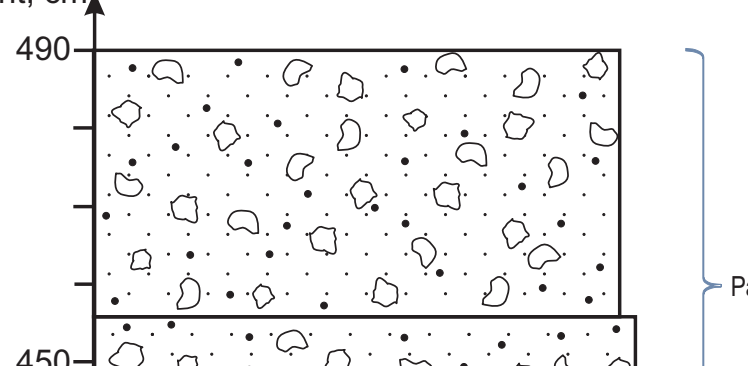<smiles>C1CCCC1</smiles>

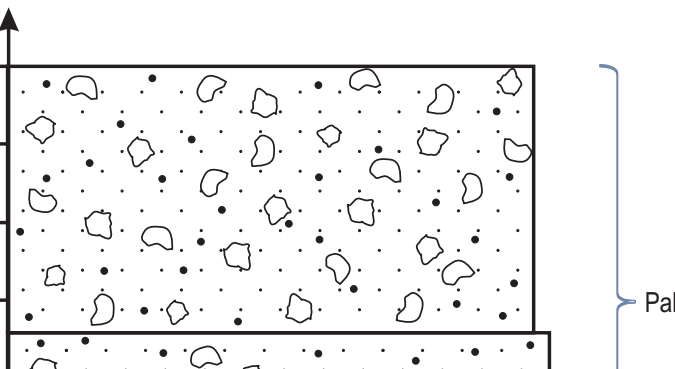

Palagonitized LT

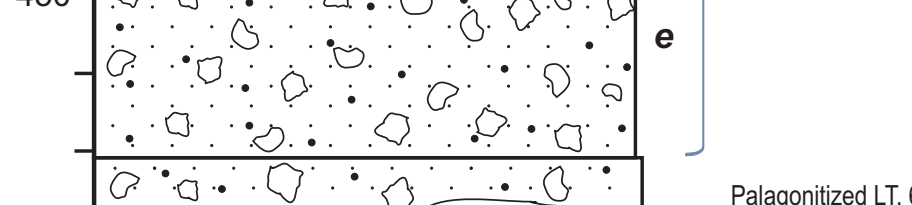

lapilli with one dense volcanic block (65 x

$37 \mathrm{~cm}$ ) containing

peridotite nodules
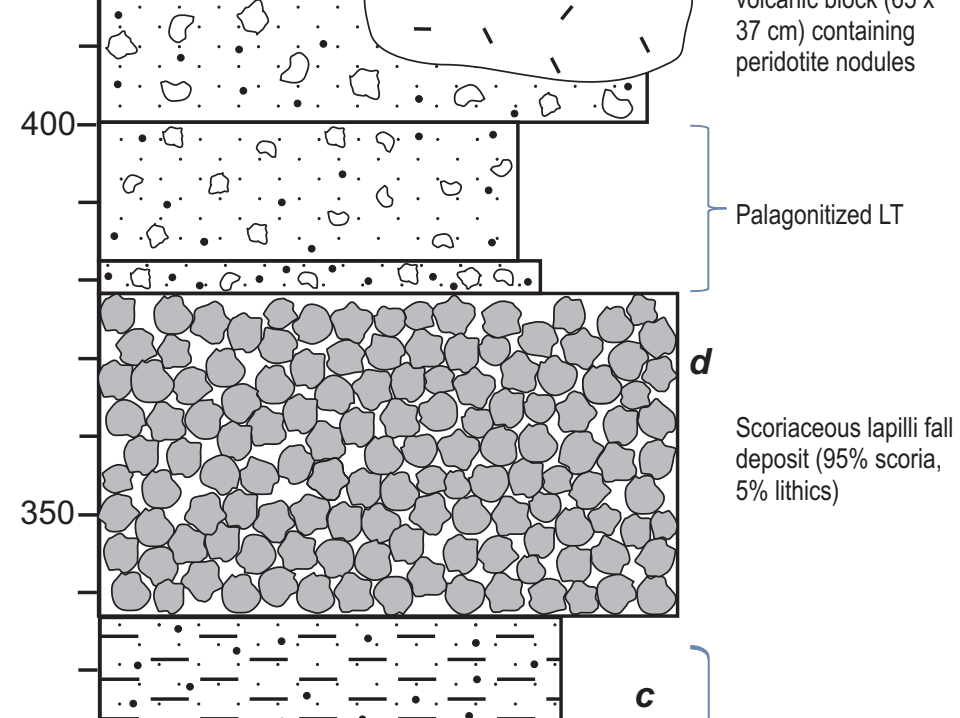
$5 \%$ lithics)

Palagonitized LT, T

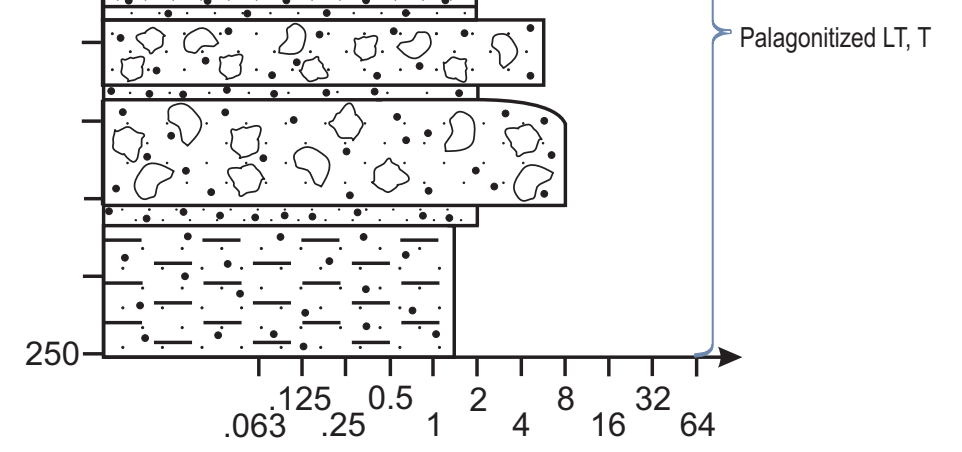



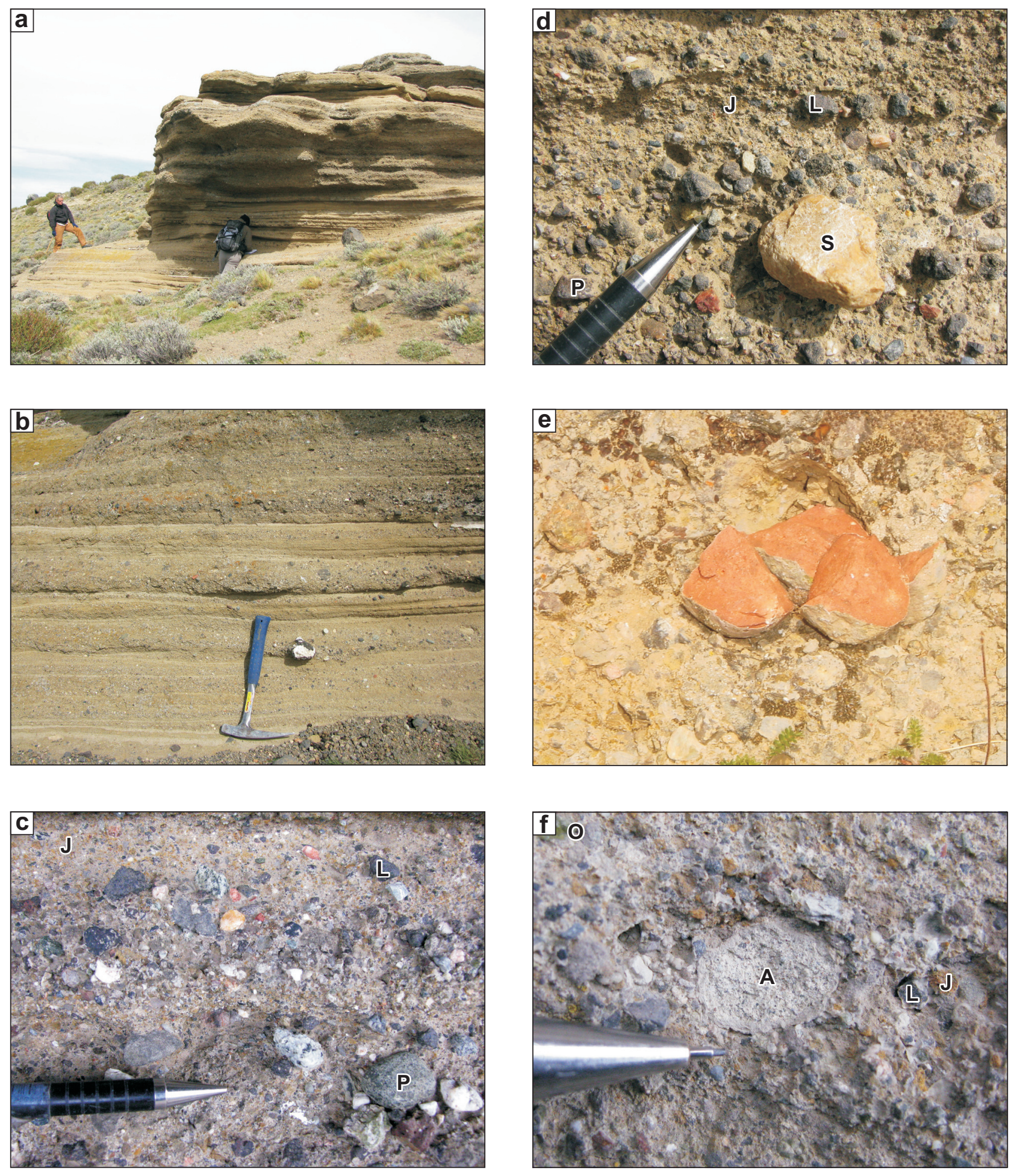

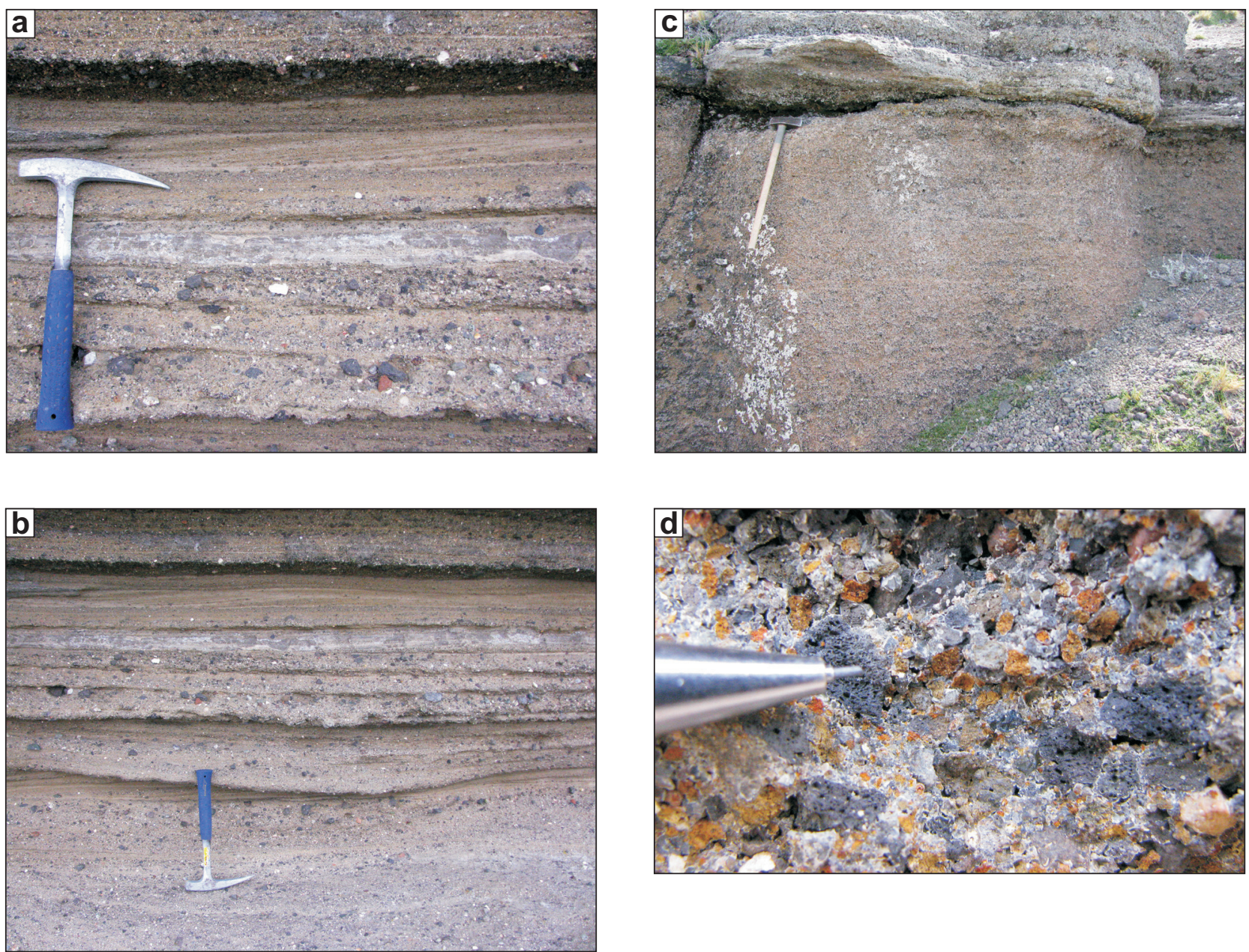

Ross et al. JVGR - Fig 08 

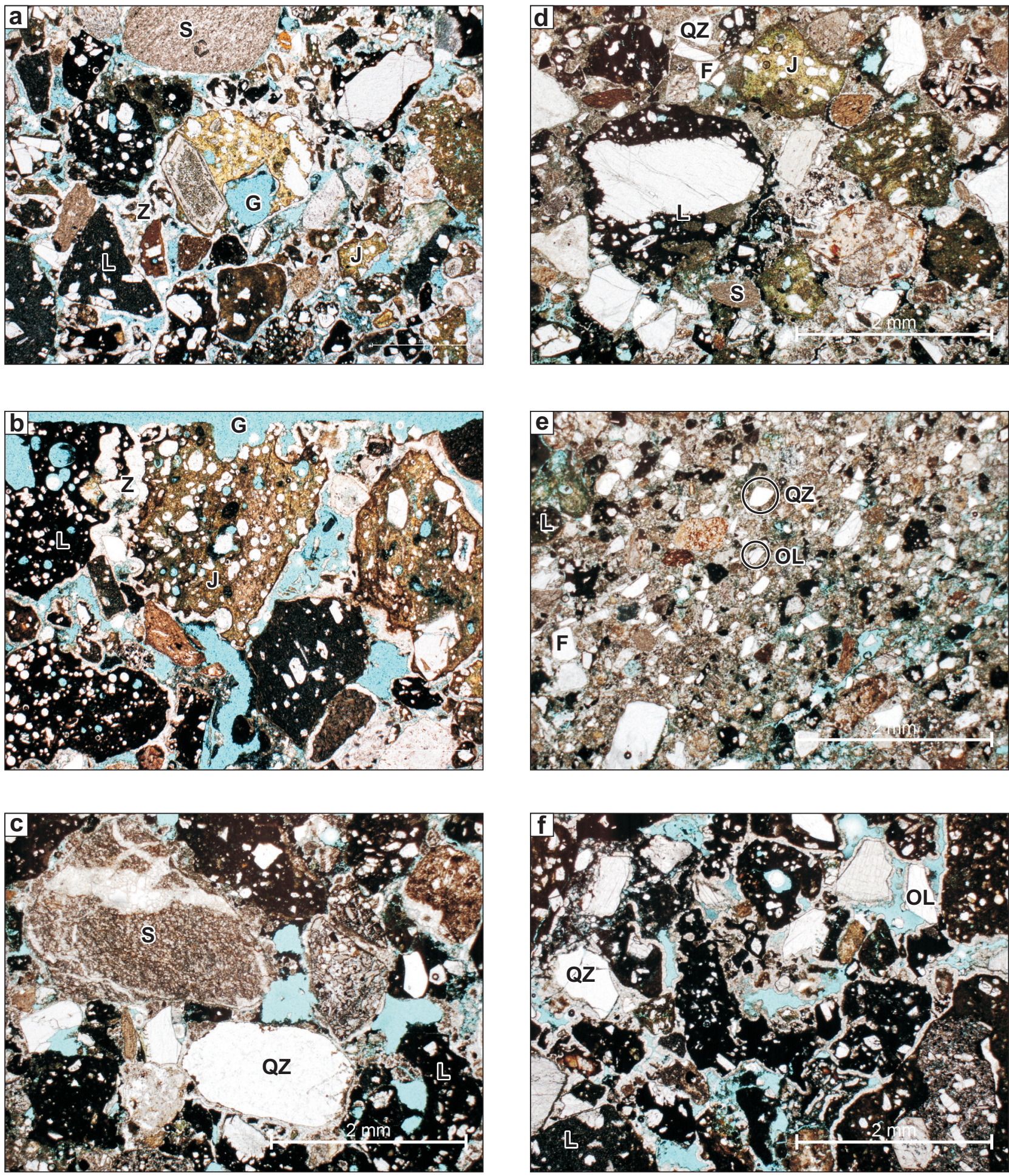

$$
\text { SCALE FOR ALL PHOTOS: } 1 \text { mm }
$$



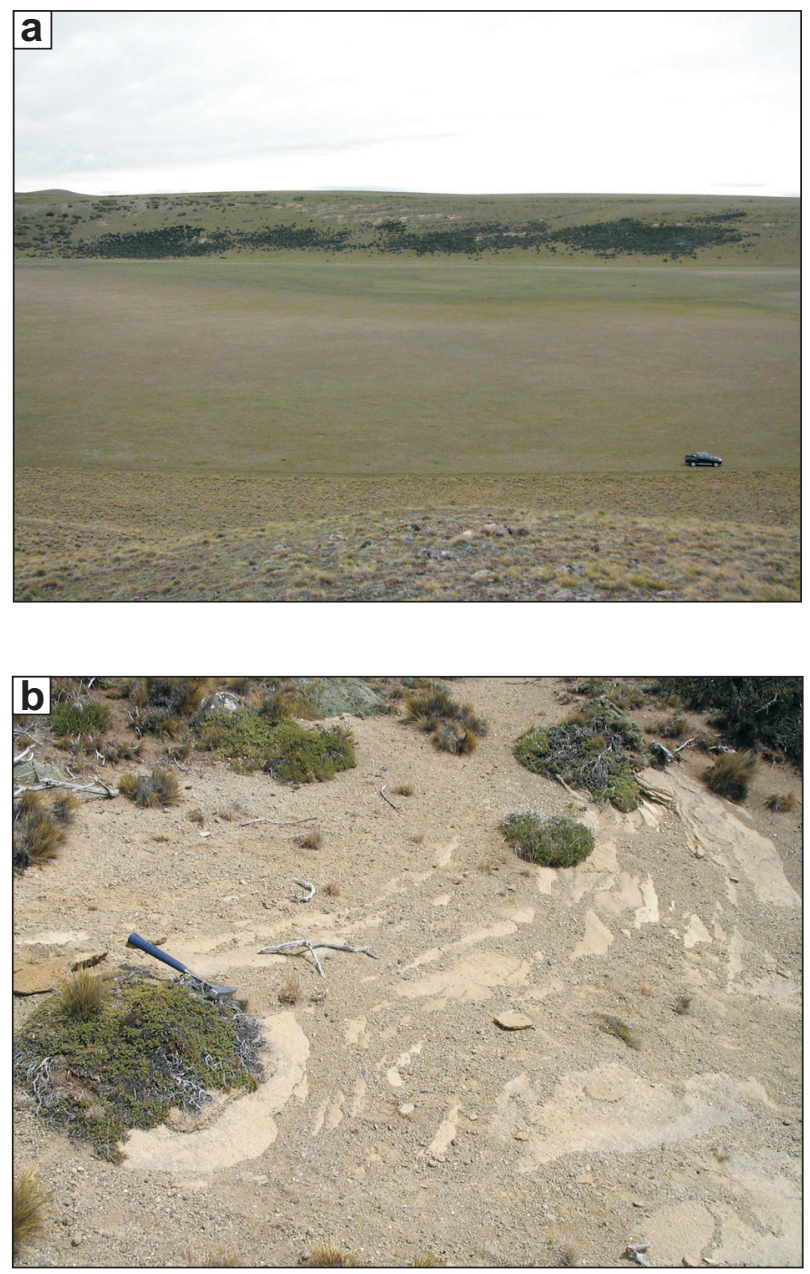

Ross et al. JVGR - Fig 10 

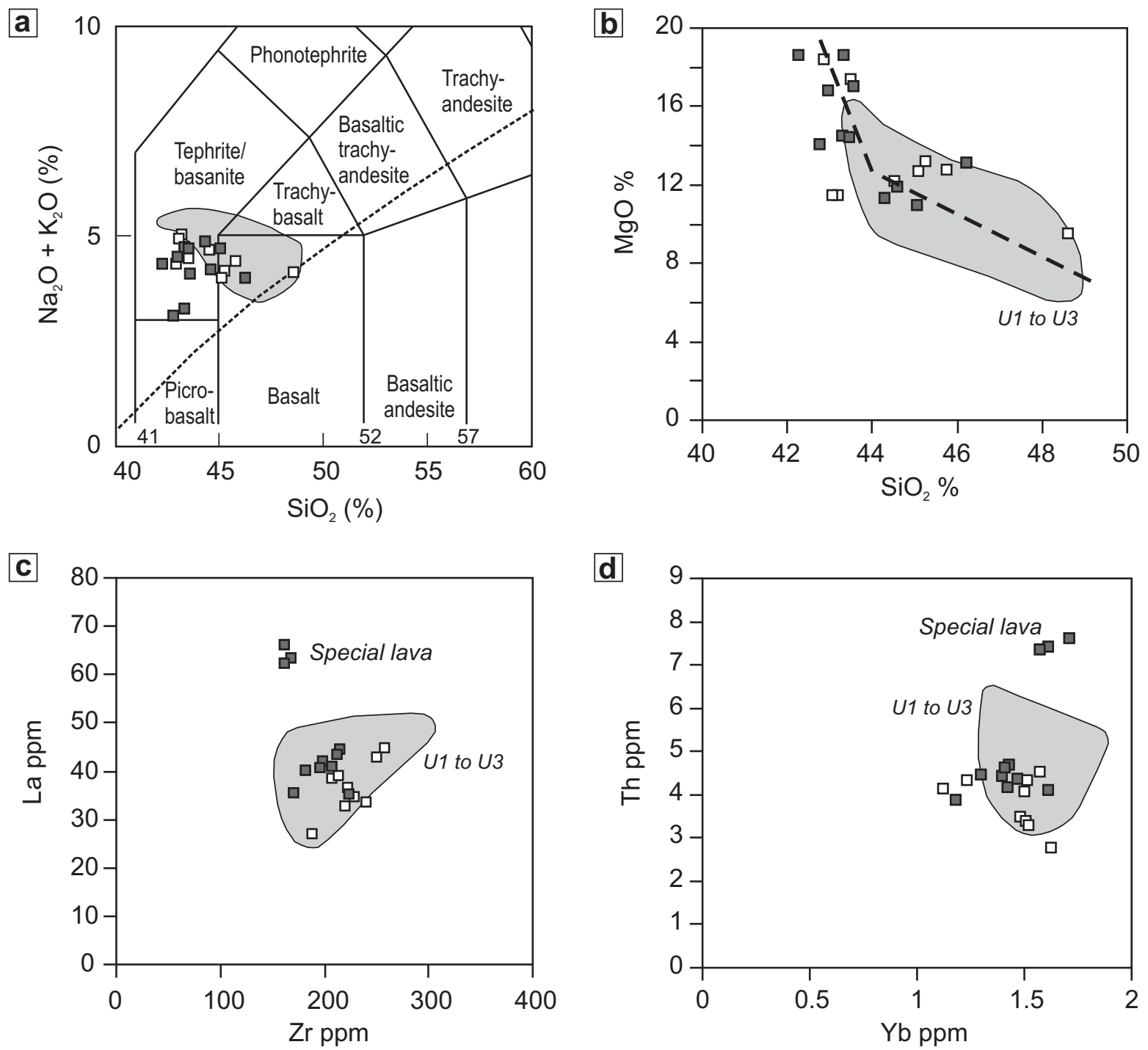

e

f

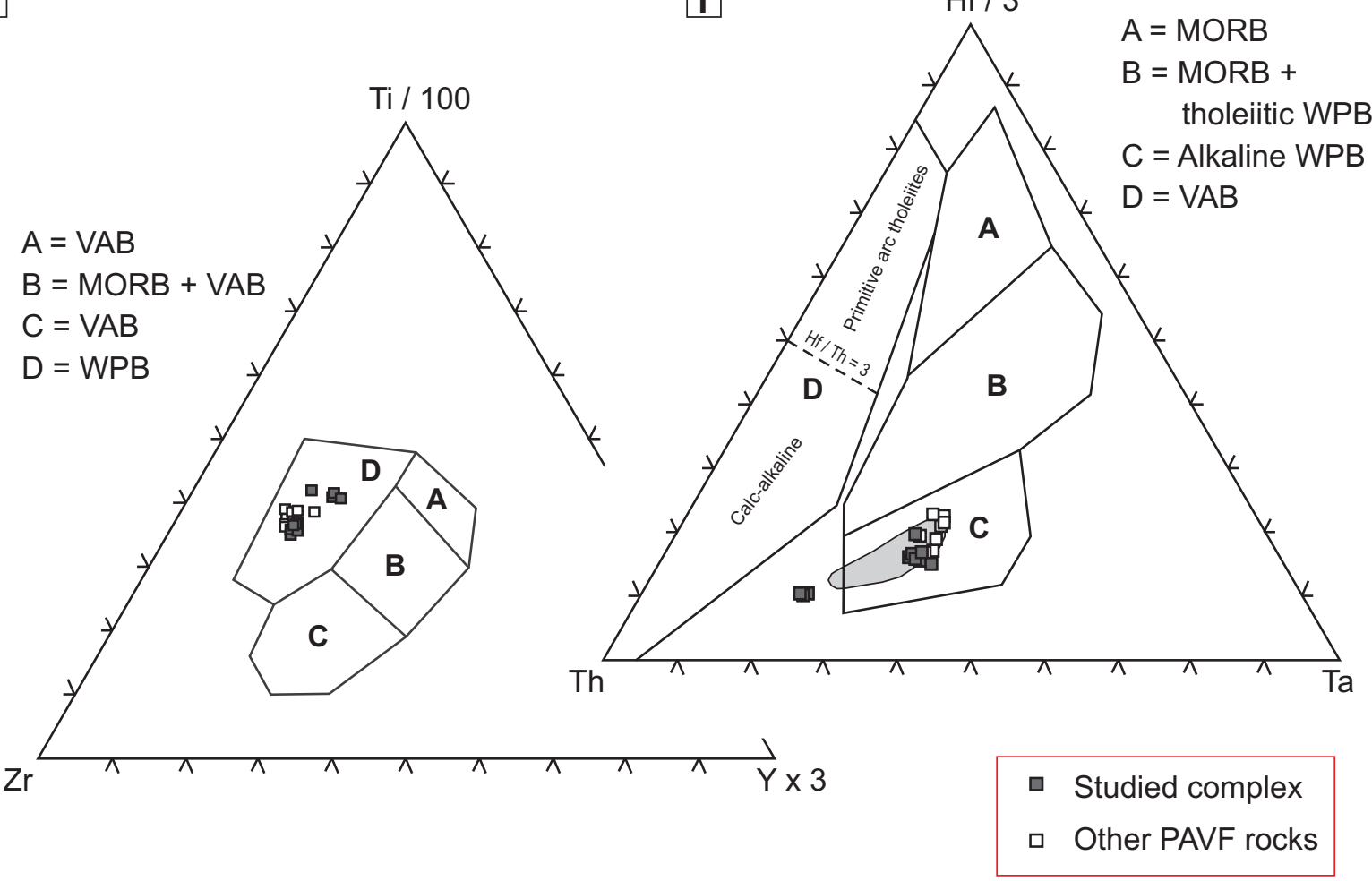

Ross et al. JVGR - Fig 11 
a

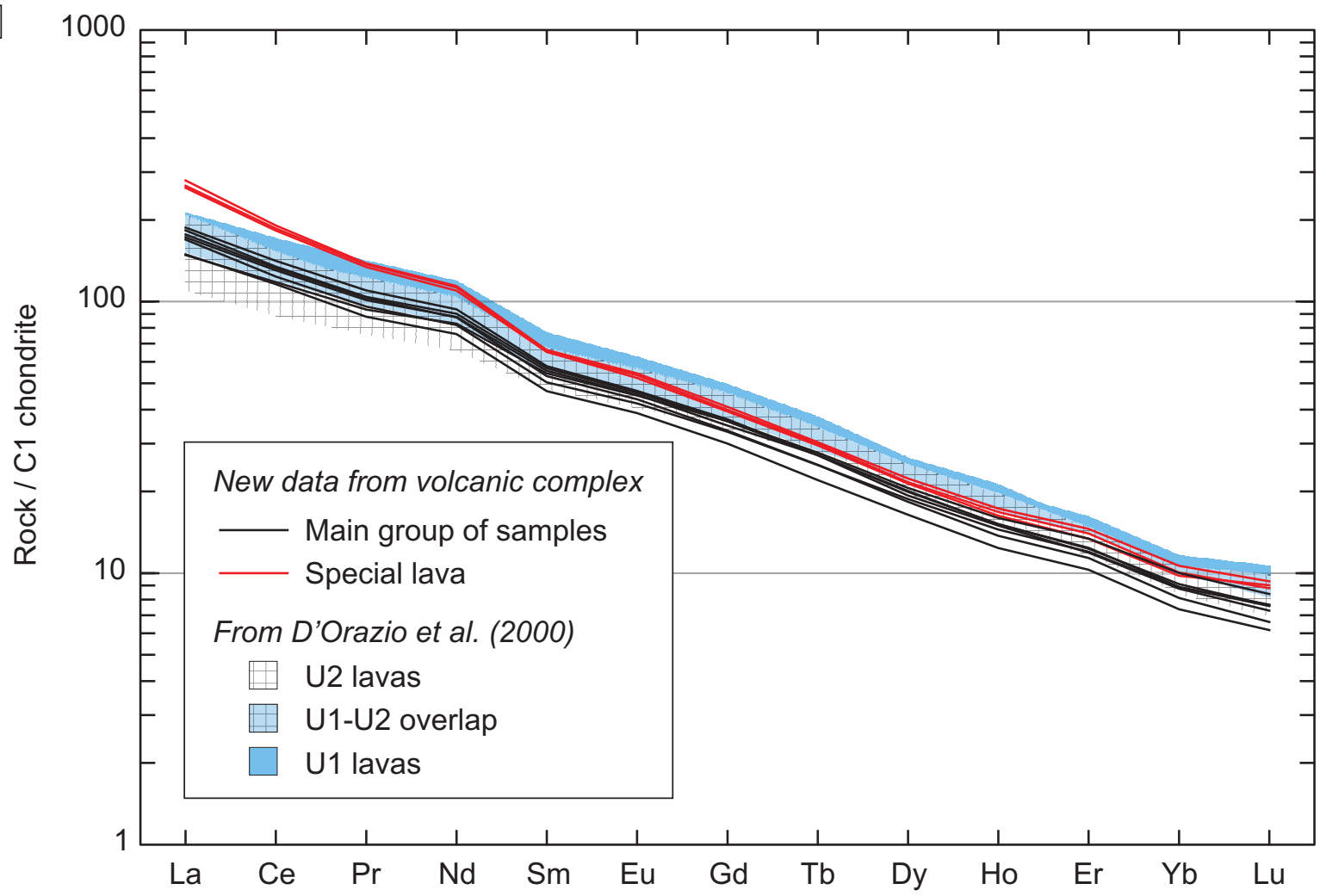

b

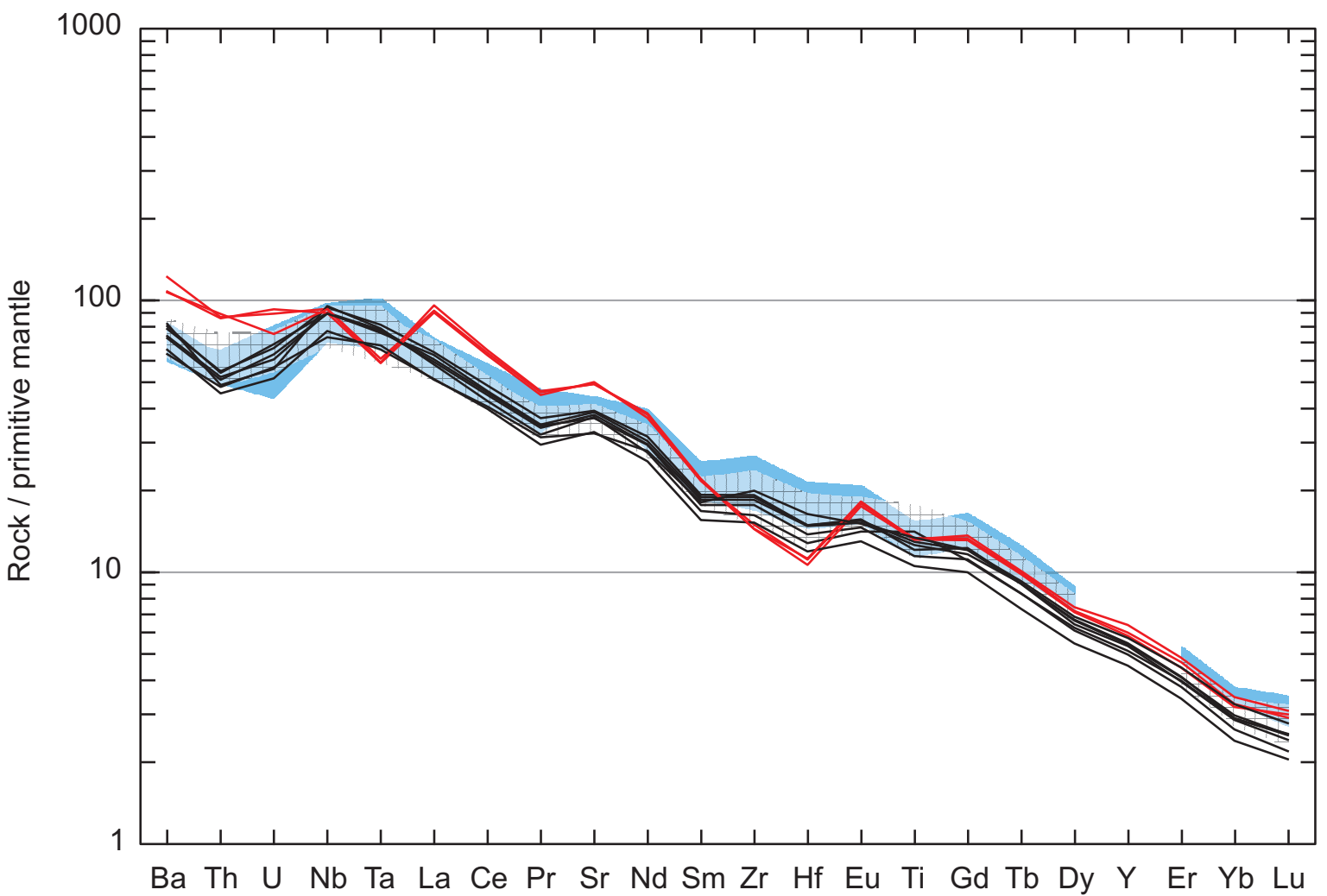


HARD SUBSTRATE
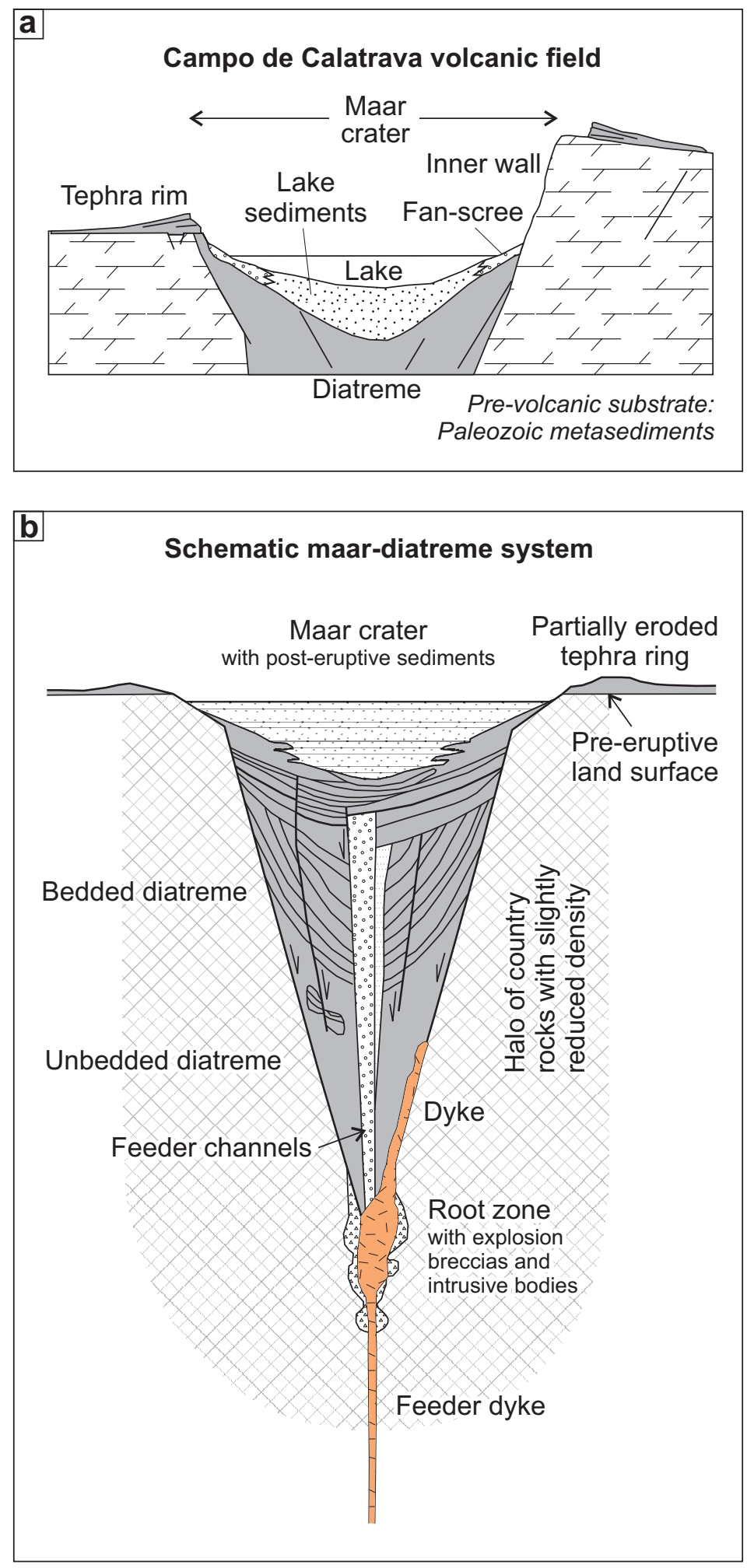

SOFT SUBSTRATE

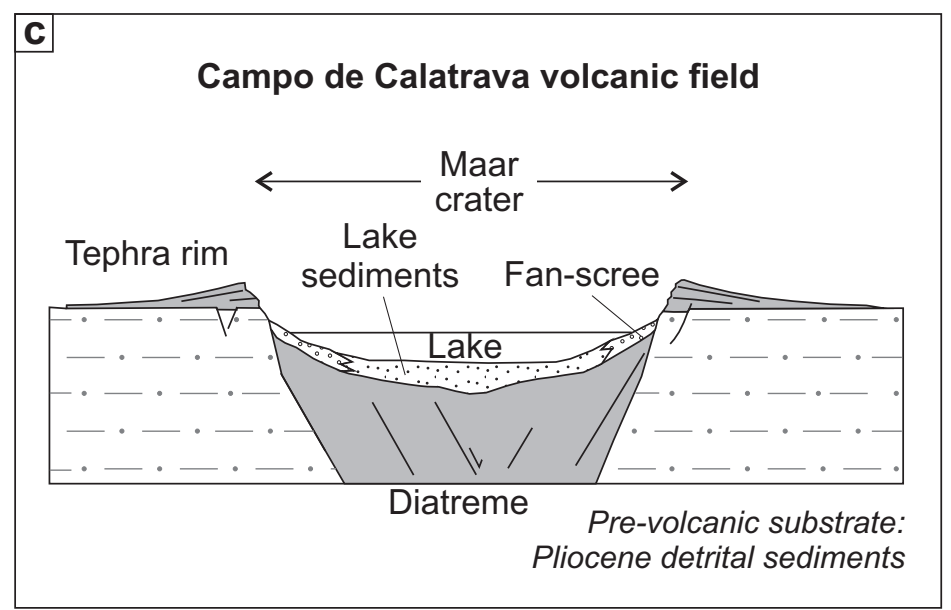

d
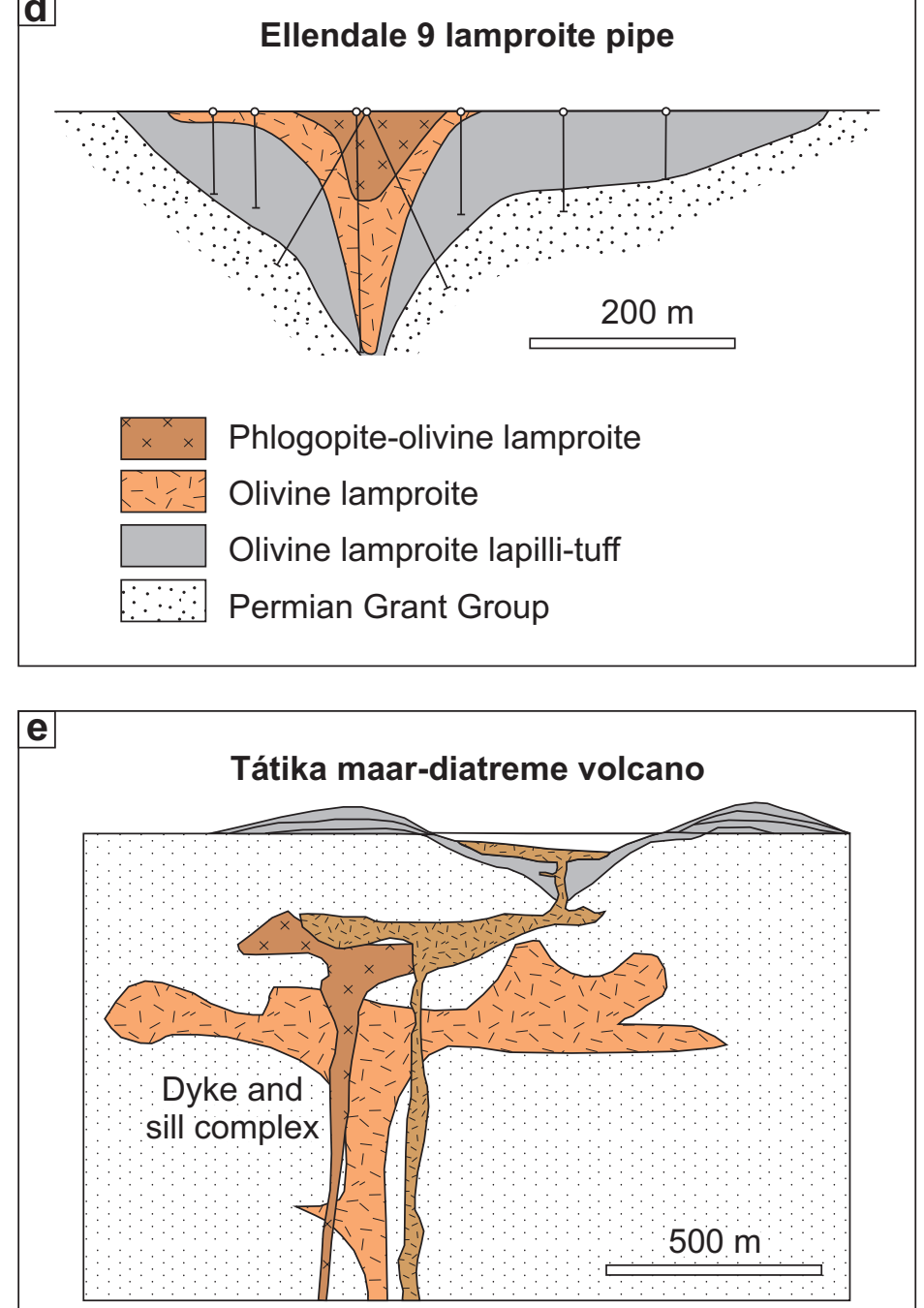


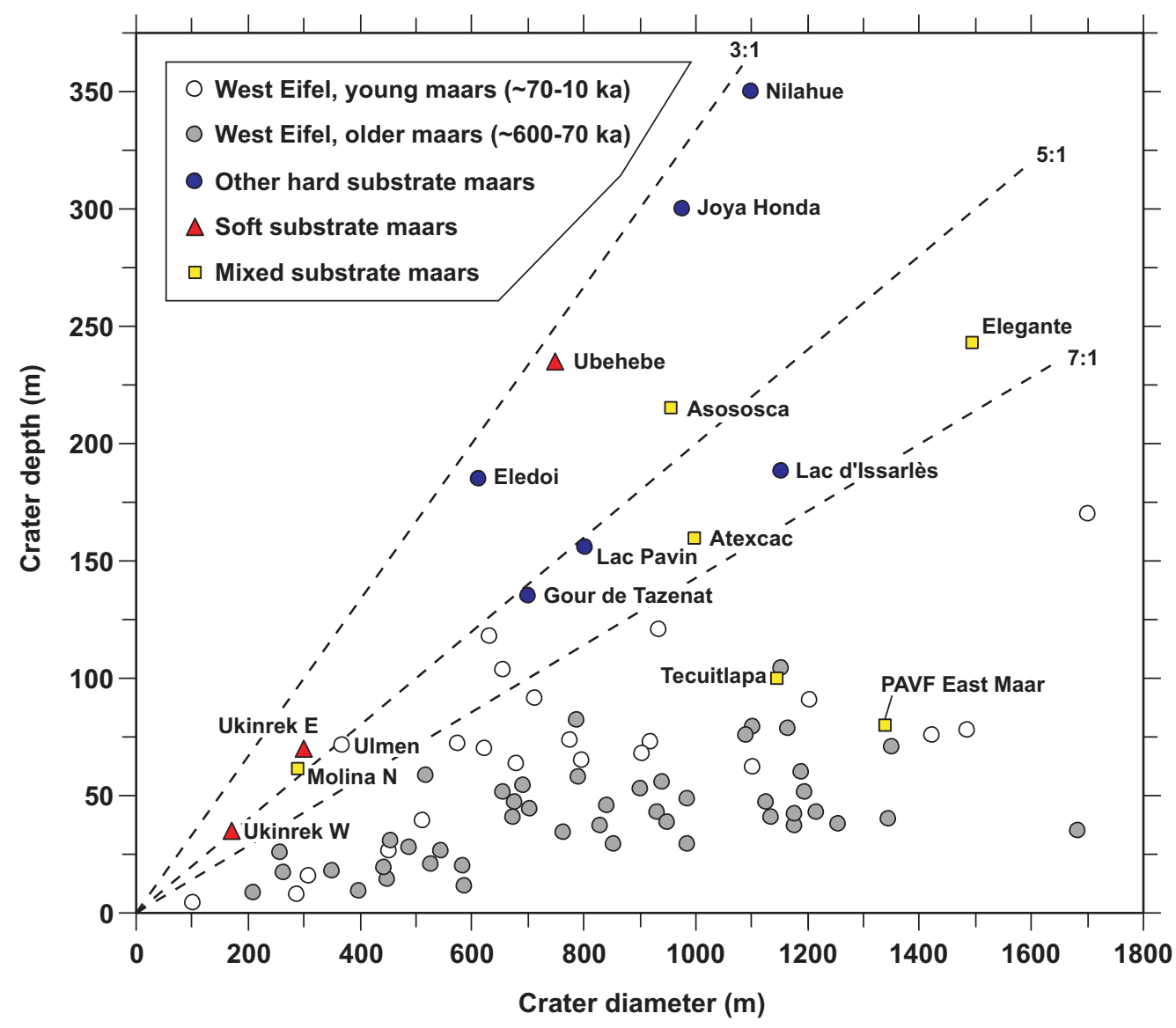

Ross et al. JVGR - Fig 14 